\title{
Role of ruthenium on the catalytic properties of CeZr and CeZrCo mixed oxides for glycerol steam reforming reaction towards $\mathrm{H}_{2}$ production
}

\author{
L. M. Martínez $\mathrm{T}^{1,2}$, M. Araque ${ }^{1}$, M. A. Centeno ${ }^{2}$, A. C. Roger ${ }^{1, *}$ \\ ${ }^{1}$ Institut de Chimie et Procédés pour l'Energie l'Environnement et la Santé ICPEES, équipe "Energie \\ et Carburants pour un Environnement Durable", UMR CNRS 7515, ECPM - Université de \\ Strasbourg, 25 rue Becquerel, 67087 Strasbourg Cedex 2, France \\ ${ }^{2}$ Departamento de Química Inorgánica - Instituto de Ciencia de Materiales de Sevilla. Centro mixto \\ Universidad de Sevilla - CSIC, Avda. Américo Vespucio 49, 41092, Sevilla, España \\ *email: annececile.roger@unistra.fr
}

\begin{abstract}
The effect of ruthenium on the physico-chemical properties of $\mathrm{CeZr}$ and $\mathrm{CeZrCo}$ mixed oxides for $\mathrm{H}_{2}$ production by glycerol steam reforming reaction has been studied. The combination of in situ Raman spectroscopy under both reductive and oxidative conditions, $\mathrm{H}_{2} / \mathrm{O}_{2}$ pulses and XRD, Raman, BET analysis, $\mathrm{H}_{2}$-TPR and TPD-TPO analyses contributed to the determination of the structural and textural properties, redox behavior, re-oxidation capacity and resistance to carbon deposition of the synthesized catalysts. The results show that the catalytic activity is improved by the (positive) cooperative and complementary effect between cobalt and ruthenium that favors the selectivity towards the steam reforming, selective to $\mathrm{H}_{2}$, with respect to the unselective thermal decomposition of glycerol. Ruthenium stabilizes the cobalt cations inserted in the fluorite structure preventing its rejection as $\mathrm{Co}_{3} \mathrm{O}_{4}$; and provides the necessary hydrogen to reduce $\mathrm{Ce}^{4+}$. The combination cobalt-ruthenium modifies positively the redox properties of the catalysts, increases the re-oxidation capacity (OSC) and promotes the gasification of the carbon deposits. Under the reaction conditions, the decrease in glycerol conversion came along with a change of selectivity. The formation of $\mathrm{H}_{2}$ and $\mathrm{CO}_{2}$ were strongly decreased, while the formation of $\mathrm{CO}, \mathrm{C}_{2} \mathrm{H}_{4}$ and condensable products (mainly hydroxyacetone) increase. The differences in the catalytic stability and activity of the catalysts are related to the capability of the catalysts to activate $\mathrm{H}_{2} \mathrm{O}$ under the reaction conditions, favoring the steam reforming reaction over the thermal decomposition.
\end{abstract}


Keywords: hydrogen production; glycerol steam reforming; mixed oxides; ruthenium; cobalt; fluorite; glycerol decomposition 


\section{Introduction}

Glycerol is a highly functionalized molecule. Its specific physical and chemical properties made of it a really attractive platform molecule, from which a large number of topvalue chemicals can be obtained [1]. Glycerol can be used as additive in several products as well as feedstock for several processes [2]. One of the most important alternatives for glycerol valorization is the production of ethylene glycol and propylene glycol by hydrogenolisis [3]. They are important in the production of polymers and resins. Selective oxidation of glycerol could lead to the production of glyceric acid and dihydroxyacetone, among others, that are considered as potentially chelating agents used as intermediates in the synthesis of fine chemicals and polymers [4].

Another alternative for glycerol valorization is the production of hydrogen. Hydrogen can be produced by pyrolysis [5], gasification [6] or reforming [7-9]. For pyrolysis and gasification, glycerol decomposition represents an important problem. Close to $290^{\circ} \mathrm{C}$ glycerol decomposes forming a mixture of acrolein, hydroxyacetone and polymerized products difficult to valorize [10-11]. For glycerol reforming three possibilities can be considered: aqueous phase reforming, steam reforming and autothermal reforming [12]. In all cases, glycerol is usually diluted with water. This considerably diminishes the mixture viscosity, facilitating its handling and processing.

Catalytic glycerol steam reforming in gas phase must be carried out at high temperature, low pressure and high steam to glycerol ratio to achieve high hydrogen yields [13-15]. In our previous studies [16] it was found that $\mathrm{H}_{2}$ production by glycerol steam reforming was optimal at temperatures higher than $650^{\circ} \mathrm{C}$, water/glycerol ratio of 9:1 and atmospheric pressure. Additionally the required catalysts should promote the gasification of the carbon deposits, favoring the preferential cleavage of C-C bonds as opposed to C-O bonds to increase the $\mathrm{H}_{2}, \mathrm{CO}_{2}$ and $\mathrm{CO}$ production [7,17] and the WGS (Water Gas Shift) reaction to convert $\mathrm{CO}$ and $\mathrm{H}_{2} \mathrm{O}$ into $\mathrm{CO}_{2}$ and $\mathrm{H}_{2}$ [18]. Ceria based catalysts are well known for their redox properties and their high performance in WGS [19]. It is known that the introduction of zirconium enhances the oxygen mobility, improving the redox properties and the oxygen buffer action observed by ceria [20]. 
Different works in steam reforming reactions have been carried out using cobalt [2122] and nickel [23] on ceria-zirconia (CZ) supports. The strong metal-support interaction reached with such mixed oxide catalysts enhances the catalytic behavior. However, the product distribution in gaseous phase changes with time on stream showing deactivation, that is related to the formation of carbonaceous deposits. In an attempt to reduce the deactivation of catalysts by carbon formation, it has been proposed to add small quantities of noble metals to the mixed oxide catalysts [24-26]. Thus the doping by rhodium decreases the formation of carbonaceous deposits [23] due to its powerful nature in breaking the C-C bonds [27].

We have recently described that the simultaneous addition of cobalt and rhodium enhanced the properties of CeZr mixed oxide [28]. High incorporation of cobalt improves the redox properties of the support and also decreases the formation of carbon deposits, thus positively affecting the catalytic properties. Rhodium has been shown to promote the stabilization of the cobalt inside the structure. This cooperative metal-metal effect decreased the $\mathrm{Co}_{3} \mathrm{O}_{4}$ spinel formation and favored the selectivity towards $\mathrm{H}_{2}$ production. In an attempt to understand the real effect of the effective incorporation of cobalt on the physicochemical properties, mixed oxide catalysts with different $\mathrm{Ce} / \mathrm{Zr}$ ratios were also studied [29] since $\mathrm{Co}^{2+}$ is normally inserted in the fluorite structure substituting $\mathrm{Zr}^{4+}$ ions [30-31]. It was demonstrated that the low content of zirconium favored the cobalt rejection, promoting the $\mathrm{Co}_{3} \mathrm{O}_{4}$ formation. Thus, the $\mathrm{Co}_{3} \mathrm{O}_{4}$ rejection should be also related to the amount of zirconium in the catalysts and not only to the stabilization of cobalt into the structure by the presence of rhodium.

The aim of this work is to provide evidence that the degree of cobalt insertion depends on the type of noble metal inserted. It is also demonstrated that the type of noble metal modifies the nature and extension of the physicochemical characteristics of mixed oxide catalysts, promoting in a different way the redox properties of the support. In the following study we present the effect of ruthenium insertion on the structural and redox properties of $\mathrm{CeZr}\left(0.65 / 0.35 \mathrm{CeO}_{2} / \mathrm{ZrO}_{2}\right.$ mass ratio) and $\mathrm{CeZrCo}$ mixed oxides. The obtained results are compared with those previously reported for similar catalysts modified by rhodium [28-29]. The possible causes of deactivation are discussed according to the characterization of spent catalysts and the analysis of the by-products. The influence of the type of noble metal on the reforming ability is presented and related to the physicochemical properties of the catalysts. 


\section{Experimental}

\subsection{Synthesis of the catalysts}

The catalysts were prepared by a pseudo sol gel method using cerium (III) acetate hydrate, zirconium (IV) acetylacetonate, cobalt (II) acetate and ruthenium (III) acetylacetonate as precursor salts. The salts were dissolved separately in propionic acid with a concentration of $0.12 \mathrm{~mol} \mathrm{\textrm {L } ^ { - 1 }}$. The solutions were mixed at $80^{\circ} \mathrm{C}$ for $1 \mathrm{~h}$ until the evaporation of the solvent. The resin obtained was heated at $2^{\circ} \mathrm{C} \min ^{-1}$ until $700^{\circ} \mathrm{C}$ and it was maintained at this temperature for $6 \mathrm{~h}$. Two kinds of catalysts with Ru were prepared: $\mathrm{Ce}_{2} \mathrm{Zr}_{1.97} \mathrm{Ru}_{0.03} \mathrm{O}_{8-\delta}(\mathrm{CZRu})$ and $\mathrm{Ce}_{2} \mathrm{Zr}_{1.5} \mathrm{Co}_{0.47} \mathrm{Ru}_{0.03} \mathrm{O}_{8-\delta}(\mathrm{CZCoRu})$. The results for the support $\mathrm{Ce}_{2} \mathrm{Zr}_{2} \mathrm{O}_{8}(\mathrm{CZ})$ and for the monometallic mixed oxide catalyst $\mathrm{Ce}_{2} \mathrm{Zr}_{1.5} \mathrm{Co}_{0.5} \mathrm{O}_{8-\delta}(\mathrm{CZCo})$ were also included.

\subsection{Glycerol steam reforming conditions}

The catalytic test and the analytical method used to evaluate the catalytic performance of the catalysts were both described elsewhere [16,28]. For the reaction, $55 \mathrm{mg}$ of catalysts diluted with $55 \mathrm{mg}$ of $\mathrm{SiC}(\mathrm{SICAT} \AA)$ ) were placed in a straight tubular quartz reactor at atmospheric pressure for $24 \mathrm{~h}$. Before reaction all the catalysts were reduced in-situ at $450^{\circ} \mathrm{C}$ for $12 \mathrm{~h}$ with $3 \mathrm{ml} \mathrm{min}^{-1}$ of $\mathrm{H}_{2}$. The reactant solution was a mixture of glycerol from Sigma Aldrich $99.0 \%$ and deionized water (1:9 molar ratio). The reactant solution was pumped into the system using a Gilson 350 micropump that corresponds to $0.0213 \mathrm{~g}$ solution $\mathrm{min}^{-1}$ liquid flow (equivalent to $19 \mathrm{~mL} \mathrm{~min}^{-1}$ of $\mathrm{N}_{2}$ :Ar; 1:4 molar ratio) and it was introduced into the reactor by a needle.

The condensable by-products were collected in two traps: the first one at room temperature and the second one at $0^{\circ} \mathrm{C}$. The collect was done after $5 \mathrm{~h} ; 8.5 \mathrm{~h}$ and $24 \mathrm{~h}$ of reaction. The products were analyzed by gas chromatography using a ZB-Wax Plus (Zebron) column with n-propanol as internal standard. The detection of acetone, acetaldehyde, acroleine, methanol, ethanol, hydroxyacetone, acetic acid, propionic acid, propylenglycol, ethyleneglycol, glyceraldehyde and glycerol was done, and this fraction was called condensable products. Simultaneously every $30 \mathrm{~min}$ the non-condensable products $\left(\mathrm{H}_{2}, \mathrm{CO}\right.$, 
$\mathrm{CO}_{2}, \mathrm{CH}_{4}$ and $\mathrm{C}_{2} \mathrm{H}_{4}$ ) were analyzed by on-line gas chromatography using a Carbosieve II column.

The global conversion of glycerol (X - Equation 1) was determined from the glycerol recovered from the condensable phase. The conversion towards non-condensable $\left(\mathrm{X}_{\mathrm{G}}-\right.$ Equation 2) and condensable $\left(\mathrm{X}_{\mathrm{L}}\right.$ - Equation 2) products were also quantified. All the values are shown as weighted mean with time taking into account the reaction time selected to recover the condensable products.

$$
\begin{gathered}
\mathrm{X}=\left[1-\frac{\mathrm{g}_{\mathrm{Gly} . \text { out }}}{\mathrm{g}_{\mathrm{Gly} \text {.in }}}\right] \\
\mathrm{X}_{\mathrm{G}}=\frac{\mathrm{F}_{\mathrm{CO}_{2}}+\mathrm{F}_{\mathrm{CO}+\mathrm{F}_{\mathrm{CH}_{4}}+2 \mathrm{~F}_{\mathrm{C}_{2} \mathrm{H}_{4}}} * 100}{3 \mathrm{~F}_{\mathrm{Gly} . \mathrm{in}}} \\
\mathrm{X}_{\mathrm{L}}=\frac{\sum \mathrm{F}_{\mathrm{X}}}{3 \mathrm{~F}_{\mathrm{Gly} . \mathrm{in}}} * 100
\end{gathered}
$$

where $\mathrm{F}_{\mathrm{X}}$ is the molar flow of $\mathrm{x}$; $\mathrm{g}_{\mathrm{Gly} \text {.out }}$ is the mass of exhaust glycerol for a given period of time, and $\mathrm{g}_{\mathrm{Gly} . \mathrm{in}}$ is the mass of glycerol introduced to the system for the same period of time.

\subsection{Catalysts characterization}

- The experimental composition of the mixed oxides was determined by Inductively Coupled Plasma (ICP) in a Fison ARL-3410 equipment (Central Analysis Service of CNRS in Vernaison - France).

- The crystalline structure of the mixed oxides catalysts was determined by XRD in a Brucker AXS-D8 Advanced equipment with $\mathrm{Cu}$ K $\alpha$ radiation $(\lambda=1.5404 \AA)$. The $2 \theta$ range scatter was from $10^{\circ}$ to $90^{\circ}$ with a $0.05^{\circ}$ step size at a scan rate of $3 \mathrm{~min}^{-1}$.

- The Raman spectra of the fresh catalysts were recorded in a dispersive Horiva Jobin Yvon LabRam HR800 microscope with a He-Ne green laser (532.14 nm) working at 5mW, and with a $600 \mathrm{~g} \bullet \mathrm{mm}^{-1}$ grating $(0.87 \mu \mathrm{m}$ spot laser $)$. The microscope used a 50x objective and a confocal pinhole of $1000 \mu \mathrm{m}$. The Raman spectrometer was calibrated using a silicon wafer. 
- For the in-situ Raman spectroscopy, a Linkam CCR100 cell was coupled to the Raman equipment. In this case, cycles of reduction and re-oxidation using $\mathrm{H}_{2}$ pure and synthetic air were done. The temperature was increased at $10^{\circ} \mathrm{C} \mathrm{min}^{-1}$ from room temperature to $450^{\circ} \mathrm{C}$ for the reduction part and to $550^{\circ} \mathrm{C}$ for the oxidation part. The spectra were obtained each $100^{\circ} \mathrm{C}$ after $15 \mathrm{~min}$ of stabilization. The microscope used a $20 \mathrm{x}$ objective and a confocal pinhole of $1000 \mu \mathrm{m}$ with spot laser of $1.62 \mu \mathrm{m}$.

- Specific surface areas were determined by nitrogen physisorption measurements at 77 K (Brunauer-Emmett-Teller, BET method) using a COULTER SA 3100 equipment. Prior to the analysis, the samples were outgassed at $250{ }^{\circ} \mathrm{C}$ for $16 \mathrm{~h}$.

- $\mathrm{H}_{2}$-TPR analyses were carried out in a Micromeritics AutoChem II 2920 equipment with a TCD detector. The analysis was performed on $30 \mathrm{mg}$ of fresh catalyst with $50 \mathrm{~mL} \mathrm{~min}^{-}$ ${ }^{1}$ of a $10 \% \mathrm{H}_{2} / \mathrm{Ar}$ mixture. The temperature was increased at $15^{\circ} \mathrm{C} \mathrm{min}^{-1}$ from room temperature to $1000^{\circ} \mathrm{C}$. The total $\mathrm{H}_{2}$ consumption and the percentage of cerium reduced were calculated from the integration of TPR results. The $\mathrm{H}_{2}$ consumption was divided in two regions: at low $\left(25^{\circ} \mathrm{C}-550^{\circ} \mathrm{C}\right)$ and high $\left(550^{\circ} \mathrm{C}-100^{\circ} \mathrm{C}\right)$ temperatures. The corresponding percentage of reduced cerium was calculated with respect to the global $\mathrm{H}_{2}$ consumption. The percentage of reduced cerium $\left(\mathrm{Ce}^{4+}\right.$ to $\left.\mathrm{Ce}^{3+}\right)$ was determined assuming a total reduction of $\mathrm{Co}_{3} \mathrm{O}_{4}$ to $\mathrm{Co}^{0}$ and $\mathrm{Ru}_{2} \mathrm{O}_{3}$ to $\mathrm{Ru}^{0}$.

- The TPD-TPO analyses were carried out in a Micromeritics AutoChem II 2920 equipment. The products were followed by mass spectrometry using an OmnistarTM equipment. $20 \mathrm{mg}$ of spent catalyst were submitted to $50 \mathrm{ml} \mathrm{min}{ }^{-1}$ of pure $\mathrm{He}$ for the

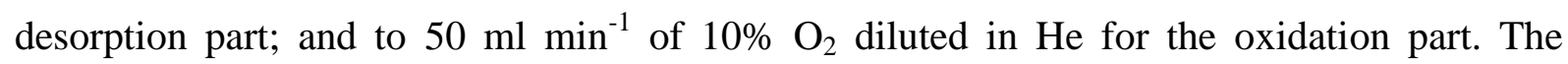
temperature was increased from room temperature until $1000{ }^{\circ} \mathrm{C}$ at $15^{\circ} \mathrm{C} \mathrm{min}^{-1}$. The $\mathrm{m} / \mathrm{z}$ signals $16,18,28,32$ and 44 were registered. However, only the results of the $\mathrm{m} / \mathrm{z} 44\left(\mathrm{CO}_{2}\right.$ signal) are shown. The selectivity of the catalysts to form carbon deposits during glycerol steam reforming was calculated as the ratio between the amount of carbon obtained from TPD-TPO analysis and the amount of carbon converted during the catalytic reaction $\left(\mathrm{S}_{\mathrm{C}}=\right.$ mmolC $_{\text {total }}$ molC $_{\text {converted }}{ }^{-1}$ ). 
- The re-oxidation and re-reduction capabilities were studied using $\mathrm{H}_{2}$ and $\mathrm{O}_{2}$ pulses until no further $\mathrm{H}_{2}$ and $\mathrm{O}_{2}$ consumptions. In both cases, pulses of $500 \mu \mathrm{L}$ of $\mathrm{H}_{2}$ or $\mathrm{O}_{2}$ were passed throughout the catalyst at $650{ }^{\circ} \mathrm{C}$. First, $20 \mathrm{mg}$ of the fresh catalysts were reduced by 30 pulses of $10 \% \mathrm{H}_{2} / \mathrm{Ar}$. Then, the catalysts were re-oxidized with 10 pulses of $10 \% \mathrm{O}_{2} / \mathrm{He}$. Finally, the catalysts were again reduced by 40 pulses of $10 \% \mathrm{H}_{2} / \mathrm{Ar}$. The experiments were performed in a Micromeritics AutoChem II 2920 equipment using a TCD detector.

\section{Results and discussion}

\subsection{Catalysts characterization before reaction}

Table 1 shows the experimental composition of the synthesized mixed oxides catalysts and the ratio $\mathrm{Ce} / \mathrm{Zr}$ determined by ICP. The experimental compositions of all catalysts were similar to the expected ones. That confirms the effectiveness of the synthesis method employed to prepare mixed oxide catalysts with the appropriate stoichiometry.

The formation of the fluorite structure was verified by XRD (Fig. 1A). All samples show diffraction lines of fluorite cubic structure $\mathrm{Ce}_{0.6} \mathrm{Zr}_{0.4} \mathrm{O}_{2}$ (JCPDS 38-1439) at $2 \theta=29.1^{\circ}$, $33.7^{\circ}, 48.5^{\circ}, 57.5^{\circ}, 60.4^{\circ}, 71.5^{\circ}$ and $78.5^{\circ}$. Peaks related to $\mathrm{RuO}_{2}(\mathrm{JCPDS}$ 01-070-2662) are not noticed due to the low quantity of ruthenium in the catalysts below the detection limit of XRD technique. For CZCo and CZCoRu small diffraction lines at $36.8^{\circ}$ and $65.2^{\circ}$ are also observed. They are attributed to $\mathrm{Co}_{3} \mathrm{O}_{4}$ spinel phase (JCPDS 43-1003). This phase has been already observed in similar CZCo catalysts [16]. It was related to an incomplete integration of cobalt into the fluorite structure.

Table 2 shows the cubic lattice parameter values of the fluorite structure calculated from the five most intense diffraction peaks for [111], [200], [220], [311] and [222] planes observed in Fig. 1A. For $\mathrm{CeO}_{2}$ this parameter has been reported close to $5.41 \AA$ [32]. $\mathrm{Zr}^{4+}$ in $\mathrm{CZ}$ decreases the lattice parameter down to $5.28 \AA$ due to the lower ionic radii of $\mathrm{Zr}^{4+}(0.84$ $\AA)$ with respect to $\mathrm{Ce}^{4+}(0.97 \AA)$ that constrains the structure. Cobalt presence increases this value up to $5.30 \AA$ for CZCo catalyst. XANES experiments demonstrated that by an appropriated method of synthesis, Co can be inserted as $\mathrm{Co}^{2+}$ in $\mathrm{CZ}$ fluorite type oxides [30]. $\mathrm{Co}^{2+}$ in octahedral coordination modifies the local environment of $\mathrm{Ce}^{4+}$ and $\mathrm{Zr}^{4+}$ since $\mathrm{Co}^{2+}$ cations can partially substitute $\mathrm{Zr}^{4+}$ cations in the $\mathrm{CZ}$ lattice. The smaller ionic radius of $\mathrm{Co}^{2+}$ 
$(0.73 \AA)$, and a higher amount of zirconium in CZCo would promote the insertion of cobalt into the lattice, decreasing the value of the lattice parameter [29]. However, the rejection of $\mathrm{Co}$ as $\mathrm{Co}_{3} \mathrm{O}_{4}$ can also occur. $\mathrm{Co}_{3} \mathrm{O}_{4}$ presence will cause an enlargement of the cubic lattice of $\mathrm{CZ}$ [30]. Probably a low Co insertion, motivated by $\mathrm{Co}_{3} \mathrm{O}_{4}$ presence, increases the cubic lattice parameter for CZCo. Ruthenium slightly decreases the lattice parameter observed for CZCo, until 5.29 $\AA$ for CZCoRu. The decrease of the cubic lattice parameter for CZCoRu, could be related to a better insertion of cobalt into the fluorite structure favored probably by a cooperative effect with ruthenium, that somehow does not facilitate the rejection of Co. The role of $\mathrm{Ru}$ in decreasing the cubic lattice parameter in $\mathrm{CZCoRu}$, is reinforced after comparing the results for both CZRu and CZCoRu, since both catalysts have the same cubic lattice parameter (5.29 ̊).

Table 2 also shows the $\mathrm{CZ}$ and $\mathrm{Co}_{3} \mathrm{O}_{4}$ crystallite size calculated from XRD patterns using the Scherrer equation. The smallest size of $\mathrm{Co}_{3} \mathrm{O}_{4}$ and $\mathrm{CZ}$ crystallites is observed for the bimetallic CZCoRu. This result is in agreement with a better insertion of cobalt into the fluorite structure promoted by the presence of ruthenium. The insertion of ruthenium also increases the surface area of $\mathrm{CZ}$ catalysts as well as the pore volume (table 2).

The structure of the catalysts was also verified by Raman spectroscopy (Fig. 1B). For $\mathrm{CZ}$ and CZRu catalysts, bands at 185, 303, 470 and $629 \mathrm{~cm}^{-1}$ are noticed. The main band at $470 \mathrm{~cm}^{-1}$ corresponds to F2g Raman active mode of fluorite type lattice [33]. The band at 303 $\mathrm{cm}^{-1}$ has been attributed to the tetragonal substitution of oxygen atoms from the ideal fluorite lattice after $\mathrm{Zr}$ insertion [34-35], while the ratio between the intensity of the band at $470 \mathrm{~cm}^{-1}$, and the intensity of the band at $629 \mathrm{~cm}^{-1}$ could be related to the oxygen vacancies, since the oxygen vacancies can increase as the intensity of the band at $629 \mathrm{~cm}^{-1}$ increases with respect to that at $470 \mathrm{~cm}^{-1}$ [36]. The increase of the relative intensity of the band at $629 \mathrm{~cm}^{-1}$ indicates a high proportion of oxygen vacancies, which could be related with the high existence of $\mathrm{Ce}^{3+}$ ions [37].

The incorporation of a high amount of $\mathrm{Zr}$ atoms in the ceria lattice generates a tetragonal phase-like distortion [38], which is observed in the intensity and location of these bands with respect to the typical $\mathrm{CeO}_{2}$ Raman spectra [29]. The integration of $\mathrm{Zr}$ into the cubic fluorite structure has been extensively studied [29,39-40]. It has been reported, that the amount of zirconium that can be effectively integrated into the fluorite is limited by the 
segregation of others crystalline phases. According to the cerium content, different crystalline phases can be formed [40-41]: one monoclinic phase (m), three tetragonal phases ( $t$, $t$ ' and t' $)$ and one cubic phase (c). At high $\mathrm{CeO}_{2}$ concentrations, the cubic phase is favored; while for the $\mathrm{ZrO}_{2}$-rich solution, the formation of a monoclinic phase is favored. For intermediate compositions, $0.3 \leq \mathrm{x} \leq 0.65\left(\mathrm{Ce}_{\mathrm{x}} \mathrm{Zr}_{1-\mathrm{x}} \mathrm{O}_{2}\right)$, the $\mathrm{t}^{\prime}$-tetragonal phase have been reported to be the most stable [39].

For CZCo and CZCoRu, bands at 191, 475, 517, 612 and $678 \mathrm{~cm}^{-1}$ are noticed in the Raman spectra. These bands have been attributed to the $\mathrm{Co}_{3} \mathrm{O}_{4}$ spinel [42]. Cobalt in the $\mathrm{CZ}$ lattice deforms the structure and affects the intensity of the fluorite structure bands that are hardly observed. The deformation of CZ structure has been reported to favor the mobility of oxygen. This improves the $\mathrm{Ce}^{4+}$ reduction. Additionally $\mathrm{Co}_{3} \mathrm{O}_{4}$ spinel bands are shifted and are broader in different zones of the sample, suggesting differences in the structure and particle size of the cobalt oxide.

Cobalt and ruthenium also modify the TPR profile of CZ (Fig. 2) lowering the reduction temperatures. $\mathrm{CZ}$ presents two reduction peaks: the first one at $620^{\circ} \mathrm{C}$, that has been associated with the reduction of $\mathrm{Ce}^{4+}$ to $\mathrm{Ce}^{3+}$ at the surface, and the second at $900^{\circ} \mathrm{C}$, associated with the reduction of bulk $\mathrm{Ce}^{4+}$ [43-44]. The presence of cobalt in CZCo promotes the reduction of surface and bulk $\mathrm{Ce}^{4+}$ at lower temperatures, thus favouring the mobility of oxygen in the bulk [45]. The formation of Co-O-Ce species has been described as responsible for the $\mathrm{Ce}^{4+}$ reduction [46]. The higher intensity and asymmetry of the peak at $450^{\circ} \mathrm{C}$ indicates the reduction of metallic particles of different size, and/or particles in different interaction with the support. The peak at $375^{\circ} \mathrm{C}$ can be attributed to the reduction of cobalt in poor interaction with the support [47]. That would correspond to the reduction of $\mathrm{Co}_{3} \mathrm{O} 4$ detected by XRD.

Ruthenium lowers even more the temperatures of reduction, providing the necessary hydrogen to reduce the bulk $\mathrm{Ce}^{4+}$ at much lower temperature than cobalt. This effect is well known for the noble metals, where the reduction of the ceria is favoured by $\mathrm{H}$-spillover from the noble metal to ceria [48-49]. For CZRu the temperatures of maximal consumption of $\mathrm{H}_{2}$ are $123^{\circ} \mathrm{C}$ and $280^{\circ} \mathrm{C}$. The peak at $123^{\circ} \mathrm{C}$ could be related to the reduction of $\mathrm{Ru}^{3+}[48,50]$. Meanwhile the peak at $280^{\circ} \mathrm{C}$ could be associated with the reduction of surface $\mathrm{Ce}^{4+}$. For 
CZCoRu an additional peak is observed at $169^{\circ} \mathrm{C}$. It could be related to the reduction of $\mathrm{Co}_{3} \mathrm{O}_{4}$.

The $\mathrm{H}_{2}$ consumption and the percentage of reduced cerium are presented in table 3 . For CZCo and CZRu the percentages of $\mathrm{Ce}^{4+}$ reduced (45 and $46 \%$ respectively) are similar to bare CZ (45\%). The overall degree of cerium reduction was only slightly affected by the presence of metallic phase. For CZCoRu, the percentage of $\mathrm{Ce}^{4+}$ reduced increases up to $56 \%$. These results confirm the positive effect of the simultaneous presence of cobalt and ruthenium in the improved reducibility of $\mathrm{CZ}$ mixed oxide. Similar results were obtained for CZCoRh catalysts [29].

\subsection{Activity results}

The $\mathrm{H}_{2}$ production obtained for 24 hours of glycerol steam reforming at $650^{\circ} \mathrm{C}$ are shown in Fig. 3 for the four CZ-based catalysts. The $\mathrm{H}_{2}$ production is expressed as mol of $\mathrm{H}_{2}$ produced per mol of glycerol introduced. At the beginning of the reaction, the presence of cobalt and/or ruthenium highly favors the $\mathrm{H}_{2}$ production with respect to bare $\mathrm{CZ}$. For $\mathrm{CZ}$, the maximal production of $\mathrm{H}_{2}$ is only $0.8 \mathrm{~mol} \mathrm{H}_{2}$ mol Gly.in ${ }^{-1}$, while for CZCo and CZRu, it is close to $5 \mathrm{~mol} \mathrm{H}_{2}$ mol Gly.in ${ }^{-1}$. After 1-2 $\mathrm{h}$, the $\mathrm{H}_{2}$ production rapidly decreases for both catalysts until a value of 0.1-1.2 mol $\mathrm{H}_{2}$ mol Gly.in ${ }^{-1}$ respectively. The profiles of $\mathrm{H}_{2}$ production reveal that the loss of activity is considerably slower for CZRu than for CZCo. The simultaneous presence of cobalt and ruthenium in CZCoRu favors the stability at higher $\mathrm{H}_{2}$ production with respect to CZRu catalyst. In this case, $6.06 \mathrm{~mol} \mathrm{H}_{2}$ mol Gly.in ${ }^{-1}$ are produced for approximately $5 \mathrm{~h}$ of reaction. After $12 \mathrm{~h}$ of reaction only $1 \mathrm{~mol} \mathrm{H}_{2}$ mol Gly.in ${ }^{-1}$ is produced. This low production is stable until $24 \mathrm{~h}$.

The performance of the catalysts towards glycerol steam reforming is better understood if the evolution of global conversion $(X)$, conversion to non-condensable products $\left(X_{G}\right)$ and conversion to condensable products $\left(X_{L}\right)$ are compared for CZRu and CZCoRu (Fig. 4). Glycerol can be efficiently transformed during the first $5 \mathrm{~h}$ of the reaction $(X \approx 100 \%)$ using CZRu and CZCoRu catalysts. However after $5 \mathrm{~h}$, it is observed that both catalysts start deactivating: the ability to convert glycerol (X) progressively decreases and the selectivity shifts from non-condensable $\left(X_{G}\right)$ to condensable products $\left(X_{L}\right)$. This effect is more visible for $\mathrm{CZRu}$ than for $\mathrm{CZCoRu}$ catalyst. The catalysts progressively lose both their capacity to 
transform glycerol besides the capacity to selectively perform the steam reforming for the $\mathrm{H}_{2}$ production.

Fig 5 shows the distribution of non-condensable products $\left(\mathrm{H}_{2}, \mathrm{CO}_{2}, \mathrm{CO}, \mathrm{CH}_{4}\right.$ and $\mathrm{C}_{2} \mathrm{H}_{4}$ ), expressed as mole of product per mole of glycerol converted into gaseous products, for CZRu and CZCoRu catalysts. In both cases, $\mathrm{H}_{2}$ is always the main product followed by $\mathrm{CO}_{2}$ and $\mathrm{CO}$. The production of $\mathrm{H}_{2}$ and $\mathrm{CO}_{2}$ decreases along with the increase of $\mathrm{CO}$ and $\mathrm{C}_{2} \mathrm{H}_{4}$. For both catalysts, the concentration of $\mathrm{CH}_{4}$ is considerably low during the whole test $(<0.25 \mathrm{~mol}$ $\mathrm{CH}_{4}$. mol gly.conv.gas ${ }^{-1}$ ). The $\mathrm{C}_{2} \mathrm{H}_{4}$ concentration increases until a maximal value of $0.3 \mathrm{~mol}$ $\mathrm{C}_{2} \mathrm{H}_{4}$. mol gly.conv.gas ${ }^{-1}$. For CZRu the decrease of $\mathrm{H}_{2}$ and $\mathrm{CO}_{2}$ selectivities starts from the beginning of the reaction.

For CZCoRu three different regions of selectivity are distinguished (Fig. 5): the first one between 0 and $6 \mathrm{~h}($ Region $\mathrm{I})$ at high and stable $\mathrm{H}_{2}$ concentrations $\left(\approx 6 \mathrm{~mol} \mathrm{H}_{2}\right.$. mol gly.conv.gas ${ }^{-1}$ ), the second one between $6 \mathrm{~h}$ and $12 \mathrm{~h}$ (Region II) at intermediate concentrations of $\mathrm{H}_{2}$; and the third one between $12 \mathrm{~h}$ and $24 \mathrm{~h}$ (Region III) at stable $\mathrm{H}_{2}$ concentration lower than $3 \mathrm{~mol} \mathrm{H}_{2}$. mol gly.conv.gas ${ }^{-1}$. In the first region the production of $\mathrm{H}_{2}$ and $\mathrm{CO}_{2}$ are favored. In the transition region, both concentrations decrease simultaneously with the increase of $\mathrm{CO}$ and $\mathrm{C}_{2} \mathrm{H}_{4}$, while in the third region, the production of $\mathrm{CO}$ and $\mathrm{C}_{2} \mathrm{H}_{4}$ are stable.

The molar fraction of principal condensable products for CZRu and CZCoRu catalysts is shown in Fig. 6. In both cases, the main product is always hydroxyacetone. It is followed by the production of acetaldehyde and acrolein, and traces of methanol. For CZRu, the acetaldehyde production decreases with time. Methanol is only formed after $5 \mathrm{~h}$ of reaction. After $5 \mathrm{~h}$, the distribution of condensable products is approximately stable. For CZCoRu no conversion to condensable products is observed in the first $5 \mathrm{~h}$ of reaction. This is consistent with a production of $\mathrm{H}_{2}$ close to the thermodynamic value (Fig. 3). From $5 \mathrm{~h}$ to $8.5 \mathrm{~h}$ only traces of hydroxyacetone are observed. After $8.5 \mathrm{~h}$ hydroxyacetone and traces of acrolein and acetaldehyde are produced. The lower formation of condensable products for CZCoRu with respect to $\mathrm{CZRu}$ is in agreement with the higher value of $X_{G}$ obtained with the former. Similar results were observed for $\mathrm{CZCoRh}$ and $\mathrm{CZRh}$ catalysts [28], where the bimetallic CoRh catalyst favored the production of non-condensable for a longer time, promoting the $\mathrm{H}_{2}$ production. 
Thanks to a similarity of the distribution byproducts obtained when $\mathrm{CZCoRu}$ is used, with the one obtained with $\mathrm{CZCoRh}$ catalyst [28], the reaction pathway to describe the glycerol steam reforming reaction should be similar whatever the noble metal used. We have already proposed a reaction pathway for glycerol steam reforming [16,28], in which the noncondensable products, $\mathrm{H}_{2}, \mathrm{CO}_{2}$ and $\mathrm{CO}$, were formed either by direct glycerol steam reforming or by steam reforming of the non-condensable products, mostly produced by thermal decomposition. At this stage, the WGS reaction should be considered to increase the formation of $\mathrm{H}_{2}$ and $\mathrm{CO}_{2}$ from the $\mathrm{CO}$ obtained after thermal decomposition. $\mathrm{CH}_{4}$ could arise from methanation of $\mathrm{CO}$, while $\mathrm{C}_{2} \mathrm{H}_{4}$ could be produced after further transformation of acetaldehyde, and/or via decarbonylation of acrolein. Hydroxyacetone, acetaldehyde and acrolein could be obtained by glycerol dehydration on acid sites.

In a previous work [28-29], we pointed out that in glycerol steam reforming at $650^{\circ} \mathrm{C}$ two effects can coexist: the catalytic effect that favors the $\mathrm{H}_{2}$ and $\mathrm{CO}_{2}$ production, and the thermal effect that promotes the glycerol decomposition. Generally, four factors determine the glycerol decomposition: the amount of water, the temperature, the packing material and the flow of inert gas. The thermal effect at temperatures higher than $600^{\circ} \mathrm{C}$ has also been pointed out by others authors [51-53]. Primary products of biomass pyrolysis (hydroxyacetone and acetic acid) have been reported as thermally unstable. For this type of products, there is a significant competition between catalytic reforming reactions and thermal decompositions [54]. According to the results above, it can be proposed that glycerol behaves as one of those products, where a significant contribution comes from the thermal decomposition.

Thermal effect was observed with a non-catalyzed catalytic bed composed only by $\mathrm{SiC}$. The results were compared with those obtained for the least active catalyst, CZ. The activity behavior was similar in both cases; the distribution of products was quite constant over the $24 \mathrm{~h}$ of reaction. The $\mathrm{H}_{2}$ production was relatively low and the proportion of $\mathrm{X}_{\mathrm{L}} / \mathrm{X}_{\mathrm{G}}$ was always relatively high. $\mathrm{CO}$ was the main product in gaseous phase followed by $\mathrm{C}_{2} \mathrm{H}_{4}$ and $\mathrm{H}_{2}$. The formation of $\mathrm{CH}_{4}$ and $\mathrm{CO}_{2}$ was also observed but in lower concentrations. Condensable products like acetic and propionic acids, and acetone were also observed in similar proportions for $\mathrm{SiC}$ and $\mathrm{CZ}$. The production of acetaldehyde was promoted to the same extent over the production of hydroxyacetone. All these byproducts suggest that the thermal decomposition of glycerol is promoted with $\mathrm{SiC}$ and $\mathrm{CZ}$. Therefore, it can be said that 
the thermal effect surpasses the catalytic reaction when the capability of the catalytic bed to activate $\mathrm{H}_{2} \mathrm{O}$ under the reaction conditions decreases. If the catalyst is active, as $\mathrm{CZCoRu}$, the steam reforming is favored (Region I - Fig. 5) over the decomposition (Region III - Fig.5). The change of selectivity (Region II - Fig 5) appears when the loss of activity is observed. At this point, the catalyst is less capable to active $\mathrm{H}_{2} \mathrm{O}$ either to reform glycerol, or to reform byproducts into $\mathrm{H}_{2}$ and $\mathrm{CO}_{2}$. Thus, the steam reforming is blocked and glycerol decomposition is observed with the formation of condensable products, $\mathrm{CO}, \mathrm{CH}_{4}$ and $\mathrm{C}_{2} \mathrm{H}_{4}$. The reforming capability is promoted by the addition of noble metal which, contrary to cobalt, improves the reforming of the decomposition products and assists the gasification of the carbon generated. The improved selectivity with the bimetallic CZCoRu could be ascribed to the enhancement of different physico-chemical properties as surface area / reducibility. All these properties could be related with a better insertion of cobalt into the fluorite structure promoted by ruthenium. These simultaneous characteristics promote the catalytic effect (Region I), and subsequently the high $\mathrm{H}_{2}$ production.

\subsection{Characterization after reaction}

In order to determine the possible causes of the deactivation in glycerol steam reforming, XRD and TPD-TPO analysis were done in the whole catalytic bed (catalyst mixed with $\mathrm{SiC}$, as diluent), since the separation of the catalyst from the $\mathrm{SiC}$ is extremely difficult. The results are explained taking into accounts that the presence of $\mathrm{Co}, \mathrm{Ru}$ or $\mathrm{CoRu}$ is the most important difference in the catalytic beds studied.

Fig. 1A shows the XRD patterns of spent CZCo and CZCoRu catalytic beds as representative diffractograms. Intensive diffraction lines of $\mathrm{SiC}$ are observed at $2 \theta=35.6^{\circ}$, $60.0^{\circ}$ and $71.6^{\circ}$ (JCPDS 03-035-0360), which considerable attenuated the peaks for $\mathrm{CZ}$ structure and $\mathrm{Co}_{3} \mathrm{O}_{4}$ observed in fresh catalysts. No peaks of $\mathrm{Ru}^{\circ}$ or $\mathrm{RuO}_{2}$ were observed, and $\mathrm{Co}^{\circ}$ was only observed in CZCo. The small increase in the lattice parameter for spent CZCoRu (table 2), with respect to CZCo, confirms that ruthenium avoids the oxidation and consequent rejection of cobalt as $\mathrm{Co}_{3} \mathrm{O}_{4}$ which causes the cell expansion.

Fig. 7 shows the TPO profiles of spent catalytic beds of CZRu and CRCoRu. Only one peak of carbon oxidation of high intensity is observed at $620^{\circ} \mathrm{C}$. Previous work with rhodium and cobalt showed two oxidation peaks [29]: one at $700^{\circ} \mathrm{C}$ and the second at lower 
temperatures $\left(<500^{\circ} \mathrm{C}\right)$. The peak at $700^{\circ} \mathrm{C}$ was correlated to the oxidation of carbon present in the catalysts like filamentous of carbon [55-56]. The presence of Co seemed to favor the formation of carbon filaments more than $\mathrm{CZ}$ or CZRh catalyst [28]. The lower temperature of carbon oxidation observed for the ruthenium catalysts $\left(620^{\circ} \mathrm{C}\right)$ may be related to a higher capacity of this noble metal to adsorb oxygen from the gas phase and spills it over to the support, favoring the oxidation of the carbon deposits at lower temperatures compared with rhodium.

The second peak of carbon oxidation, at lower temperatures, has been related to surface carbon promoted by the metallic particles on the surface [57]. The absence of low temperature oxidation for ruthenium catalysts (Fig. 7) could indicate that no metal particles remained exposed after reaction, contrary to what was observed in previous studies with rhodium. The particles could be blocked by the strong chemisorption of the intermediary species, completely covered by carbon deposits [58-60], or they could be oxidized under reaction conditions. These results shows that the type of noble metal affects in different way the reducibility/oxidation of the catalysts, that modifies the carbon desorption and consequently the catalytic performance.

The quantification of the carbon deposits obtained from the integration of TPO profiles of Figure 7 are shown in Table 4. Taking into account that the TPO analysis can help to determine a tendency of the carbon formation during the steam reforming reaction, it can be said that the presence of $\mathrm{Co}$ or $\mathrm{Ru}$ in $\mathrm{CZ}$ slightly decreases the formation of carbon. However, the simultaneous presence of cobalt and ruthenium decreases even further the amount of carbon deposits. The selectivity towards the formation of carbon deposits (SC: mmol $\mathrm{C}$ total mol $\mathrm{C}$ converted $^{-1}$ ) is also presented in table 4 . For $\mathrm{CZCoRu}$ the selectivity to carbon formation is the lowest, in agreement with the better catalytic behavior. For CZCoRu, the enhanced reducibility/oxidative properties, probably favored by the stabilization of cobalt due to the ruthenium presence, contributes to the decrease of the carbon formation. This could be related with a high gasification of the carbon by ruthenium, since noble metals are recognized by their high ability to break $\mathrm{C}-\mathrm{C}$ bonds [61]. We reported similar results for CZCoRh catalysts where the selectivity towards carbon formation was strongly decreased [29]. 
The main causes of deactivation, according to the characterization after test, are the change in the fluorite structure (enlargement of the cubic cell) and the formation of carbon deposits. For cobalt containing catalysts, the deactivation could be favored by the incomplete cobalt incorporation, which decreases the strong metal-metal interaction, and thus favors the sintering. Metal particle sintering is a well-known deactivation cause [56], closely related to the carbon formation. The formation of carbon deposits interrupts the catalyst reduction/oxidation dynamics, increasing even further the carbon deposits accumulation. Carbon can block the access to the active site or can deactivate the particles by the formation of encapsulating coke [59]. On the other hand, the formation of carbon deposits can be also related to the formation of hydroxyacetone and acrolein [62-63]. For acrolein, the production of coke has been reported by further dehydration of the molecule. For hydroxyacetone, it has been reported that it can oligomerise to form polyglycerol which may lead to coking reactions. It could explain the higher formation of carbon with monometallic catalysts, since the condensable products formation is highly favored.

In order to confirm the modification of the redox properties of the CZCo catalysts with the type of noble metal incorporated, reduction/re-oxidation/reduction pulses were performed on fresh CZCoRu and its homologous CZCoRh (Fig. 8-quantification in table 5). In the first reduction procedure (open symbols), both catalysts consume the whole incoming $\mathrm{H}_{2}(2.22$ $\mu \mathrm{mol} \mathrm{H}_{2}$ by pulse) (Fig. $8 \mathrm{~A}$ ). The reducibility is easier for $\mathrm{CZCoRh}$. It needs only 3 pulses to consume all the $\mathrm{H}_{2}$, while $\mathrm{CZCoRu}$ requires 8 pulses. For the second reduction procedure (filled symbols), CZCoRu decreases its reduction capability, while CZCoRh shows any visible differences between the two reductions steps. In fact, the hydrogen consumptions are very similar for this catalyst in both cases (table 5). This can be related with a higher reduction of cobalt, probably by the presence of lower amount of $\mathrm{Co}_{3} \mathrm{O}_{4}$ on $\mathrm{CZCoRh}$ than on $\mathrm{CZCoRu}$.

Fig. $8 \mathrm{~B}$ shows the evolution of $\mathrm{O}_{2}$ consumption with the pulse number after the first reduction. In this case, both catalysts show a faster re-oxidation of the surface compared with the reduction. This behavior have already been noticed [64] using CZ catalysts. For CZCoRu, the $\mathrm{O}_{2}$ uptake is complete for the first pulses and it decays to zero after 8 pulses $\left(660 \mu \mathrm{mol} \mathrm{O}_{2}\right.$. g catal. ${ }^{-1}$ is consumed - table 5). For CZCoRh, complete consumption of $\mathrm{O}_{2}$ is achieved for 3 pulses and no more oxygen is required after 6 pulses $\left(455 \mu \mathrm{mol} \mathrm{O}_{2}\right.$. g catal. ${ }^{-1}$ are consumed table 5). The higher capacity to store oxygen observed for CZCoRu is in accordance with the 
lower temperature of carbon oxidation obtained by TPO experiments, with respect to the temperature observed with CZCoRh.

Although CZCoRu has higher total capacity to store hydrogen and oxygen, its reduction is not complete and decreases during the second reduction stage. For CZCoRh, the reduction is easier and it is maintained after a second reduction. In this case, the re-oxidation of CZCoRh was enough to favour its complete reduction. That result can be clarified by the ratios of $\mathrm{H}_{2} / \mathrm{O}_{2}$ consumptions (table 5). For $\mathrm{CZCoRh}$ a ratio of 0.41 , closer to the stoichiometric value of 0.5 , is obtained. While for $\mathrm{CZCoRu}$, this value is 0.38 . The higher $\mathrm{O}_{2} / \mathrm{H}_{2}$ for $\mathrm{CZCoRh}$ agrees with the maximal $\mathrm{H}_{2}$ consumption observed in $\mathrm{H}_{2}$-TPR at high temperature: $1.52 \mathrm{mmol} \mathrm{H}_{2} \mathrm{~g}$ catal $^{-1}-88 \%$ of $\mathrm{Ce}^{4+}$ reduced [28], with respect to $1.15 \mathrm{mmol}$ $\mathrm{H}_{2} \mathrm{~g} \mathrm{catal}^{-1}-56 \%$ of $\mathrm{Ce}^{4+}$ reduced for $\mathrm{CZCoRu}$. The high amount of $\mathrm{Ce}^{4+}$ reduced for $\mathrm{CZCoRh}$ confims the better insertion of cobalt in the $\mathrm{CZ}$ lattice with respect to CZCoRu. These results demonstrate the different effect of the simultaneous presence of Co and $\mathrm{Ru}$ (or $\mathrm{Rh}$ ) on the reducibility of $\mathrm{CZ}$ mixed oxide and therefore on its catalytic response.

The analysis of the redox properties of the CZCo, with different noble metals incorporated, points out that in glycerol steam reforming the global capacity of $\mathrm{H}_{2}$ consumption and the capacity to be re-oxidized and re-reduced should be considerered to explain the catalytic behaviour of the catalysts. The total amount of $\mathrm{H}_{2}$ consumed was higher for $\mathrm{CZCoRh}$, that promotes the $\mathrm{Ce}^{3+}$ formation. This catalyst also shows a significantly higher re-oxidation capacity compared to $\mathrm{CZCoRu}$. The bulk of $\mathrm{CeO}_{2}$ behaves as an oxygen reservoir, supplying oxygen to the surface through a migration process; while under oxidative environment, the opposite process is likely, and the lattice oxygen is replenished by oxygen coming from the gas phase [65]. The introduction of noble metal, in a certain extent, creates a distortion of the lattice that increases the oxygen mobility in the bulk oxide. The improved oxygen mobility favours the catalytic response in steam reforming reactions. This lattice distortion has been observed by Raman experiment at room temperature for fresh CZRh and CZRu catalysts. It was higher after rhodium insertion (band at $629 \mathrm{~cm}^{-1}$ more intense for CZRh catalyst) [28] than after ruthenium insertion (Raman spectra for CZRu - Fig. 1B). This observation confirms that rhodium addition favours even more the oxygen vacancies than ruthenium, and this partially explains the better catalytic behaviour of rhodium with respect to ruthenium catalysts. Unfortunately, the oxygen vacancy bands for CZCoRu and CZCoRh 
were not observed due to the $\mathrm{Co}_{3} \mathrm{O}_{4}$ Raman bands, which superimposed with the fluorite bands.

In situ Raman spectroscopy under reductive and oxidative conditions was used to observe the structural changes of $\mathrm{CZ}$ and CZCo mixed oxide catalyst after addition of noble metal (Fig. 9). For comparative purposes the Raman spectra for CZRh and CZCoRh are also shown [28]. For CZRu and CZRh, the cubic fluorite structure is visible until $\approx 250^{\circ} \mathrm{C}$ in reductive conditions. Beyond this temperature its bands are hardly observed, which agrees with the reduction of the surface at $450^{\circ} \mathrm{C}$ suggested by TPR results (Fig. 2). The fluorite structure is again recovered when the temperature decreases. Conversely, in oxidative conditions this structure is always observed but the increase in temperature slightly decreases the intensity of the bands, suggesting modifications of the fluorite.

The intensity of the band at $629 \mathrm{~cm}^{-1}$ is always higher for CZRh. With the increase of temperature, the intensity of the band at $470 \mathrm{~cm}^{-1}$ decreases as the intensity of the band at 629 $\mathrm{cm}^{-1}$ increases. Conversely for $\mathrm{CZRu}$, the intensity of the band at $470 \mathrm{~cm}^{-1}$ increases while the intensity of the band at $629 \mathrm{~cm}^{-1}$ decreases. These results suggest that the oxygen vacancies probably are more favored on CZRh that on $\mathrm{CZRu}$, and they would indicate the positive effect of rhodium addition in the increase of oxygen mobility of $\mathrm{CZ}$, compared with the addition of ruthenium.

Other important differences in Fig. 9 are observed after addition of rhodium or ruthenium to CZCo. At the beginning of the reduction, both catalysts show typical bands of $\mathrm{Co}_{3} \mathrm{O}_{4}$ spinel. These bands are always observed until $150^{\circ} \mathrm{C}$. Beyond this temperature, the spinel phase disappears, in agreement with the reduction of the $\mathrm{Co}_{3} \mathrm{O}_{4}$ at $169^{\circ} \mathrm{C}$ suggested by the TPR results (Fig. 2).After decreasing the temperature, the fluorite structure is hardly observed. For CZCoRh the fluorite structure is again observed after 5 min in synthetic air atmosphere. During oxidation, the fluorite structure is always observed on CZCoRh and the $\mathrm{Co}_{3} \mathrm{O}_{4}$ spinel phase is no longer observed. Conversely, for CZCoRu, the fluorite structure is not recovered during oxidation conditions. However $\mathrm{Co}_{3} \mathrm{O}_{4}$ is the main structure observed even though the temperature increases. These results demonstrate that the type of noble metal favors in a different way the insertion of cobalt. Rhodium seems to inhibit the segregation of cobalt at the surface after reduction/oxidation procedure, more than ruthenium does. Thus, the type of noble metal determines the degree of stabilization of cobalt inserted in the fluorite 
structure, thus determining the degree of cobalt rejection as $\mathrm{Co}_{3} \mathrm{O}_{4}$ during reaction conditions. The increase in the incorporation of cobalt with rhodium explains the better catalytic performance of $\mathrm{CZCoRh}$ catalysts [29], with respect to its homologous with ruthenium CZCoRu (Fig. 3).

From the results and discussion the beneficial effect of the noble metal addition to the cobalt catalysts is clear for glycerol steam reforming. A high incorporation of cobalt by the noble metal stabilization modifies positively the redox behavior of the catalysts, promoting the re-oxidation capability and consequently favoring the gasification of the carbon generated. Thus, the deactivation of the catalysts can decrease and the catalysts can properly reform the glycerol into non-condensable products (mainly $\mathrm{H}_{2}$ and $\mathrm{CO}_{2}$ ) for longer time. This means an increase of the catalytic effect simultaneously with a decrease of the thermal effect by the cooperative metal-metal effect.

\section{Conclusions}

In the present study, it was proven that the different by-products obtained by glycerol steam reforming with $\mathrm{CZ}$ mixed oxide catalysts can be related with three regions of activity. The first one corresponds to a direct glycerol steam reforming with the direct productions of non-condensable products. In this region, the catalysts are highly active and selective towards $\mathrm{H}_{2}$ and $\mathrm{CO}_{2}$. The second one is observed when the global conversion decreases along with a change of selectivity, increasing the formation of condensable products (mainly hydroxyacetone), $\mathrm{CO}$ and $\mathrm{C}_{2} \mathrm{H}_{4}$, and decreasing the $\mathrm{H}_{2}$ and $\mathrm{CO}_{2}$ formation. The last region appears when the reforming capability of the catalysts decreases and the glycerol decomposition starts. The deactivation is delayed when the gasification of the carbon is promoted.

The capacity to active $\mathrm{H}_{2} \mathrm{O}$ under the reaction conditions for glycerol steam reforming with $\mathrm{CZ}$ catalysts is improved by cooperative cobalt - ruthenium effect. CZCoRu favors for a longer time the activity, selectivity and selectivity towards $\mathrm{H}_{2}$ and $\mathrm{CO}_{2}$ with respect to the others products. The incorporation of cobalt modifies positively the redox properties of the catalysts, increases the re-oxidation capacity and therefore promotes the gasification of the carbon, thus increasing the activity, stability and selectivity towards $\mathrm{H}_{2}$ production. Cobalt enhances the availability of bulk $\mathrm{Ce}^{4+}$ and ruthenium provides the necessary hydrogen to 
reduce $\mathrm{Ce}^{4+}$. The degree of cobalt incorporation is affected by the type of noble metal added since its rejection as $\mathrm{Co}_{3} \mathrm{O}_{4}$ could be more decreased with rhodium instead of ruthenium. This suggests that the (positive) cooperative and complementary metal-metal effect would be more promoted after rhodium addition.

\section{Acknowledgments}

Financial support by program ECOS-Nord No Co8P03 COLCIENCIAS / ICFES/ ICETEX (Colombia-France), program Picasso No 22905RD - No FR 2009-0105 (SpainFrance) and "Ministerio de Ciencia e Innovación" Ref. No JCI-2011-10059 (Spain) are gratefully acknowledged.

\section{References}

[1] A. Behr, J. Eilting, K. Irawadi, J. Leschinski, F. Lindner, Green Chemistry 10 (2008) 13-30.

[2] M. Pagliaro, M. Rossi, The Future of Glicerol: New usages for a versatil raw material. RSC Publishing, Cambridge (2008) 170.

[3] E. P. Maris, R. J. Davis, Journal of Catalysis 249 (2007) 328-337.

[4] M. O. Guerrero-Pérez, J. M. Rosas, J. Bedia, J. Rodríguez-Mirasol, T. Cordero, Recent Patents on Chemical Engineering 2 (2009) 11-21.

[5] T. Valliyappan, N. N. Bakhshi, A. K Dalai, Bioresource Technology 99 (2008) 4476-4483.

[6] T. Valliyappan, D. Ferdous, N. Bakhshi, A. K Dalai, Topics in Catalysis 49 (2008) 59-67.

[7] R. D. Cortright, R. R. Davda, J. A. Dumesic, Nature 418 (2002) 964.

[8] R. R. Soares, D. A. Simonetti, J.A. Dumesic, Angewante Chemie International 45 (2006) 39823985.

[9] S. Adhikari, S. Fernando, A. Haryanto, Catalysis Today 129 (2007) 355-364.

[10] A. S. de Oliveira, S. J. S. Vasconcelos, J. R. de Sousa, F. F. de Sousa, J. M. Filho, A. C. Oliveira, Chemical Engineering Journal 168 (2010) 765-774.

[11] R. Shekhar, M.A. Barteau, Surface Science 319 (1994) 298-314.

[12] X. Fan, R. Burton, Y. Zhou, The Open Fuels \& Energy Science Journal (2010) 17-22.

[13] P. D. Vaidya, A. E. Rodrigues, Chemical Enginnering and Technoly 32 (2009) 1463-1469.

[14]4 P. Ramírez de la Piscina, N. Homs, Chemical Society Review 37 (2008) 2459-2467.

[15] J. Sehested, Catalysis Today 111 (2006) 103-110.

[16] M. Araque, L. M. Martínez T., J. C. Vargas, A. C. Roger, Catalysis Today 176 (2011) 352- 356.

[17] C. T. Au, C. F. Ng, M. S. Liao, Journal of Catalysis 185 (1999) 12-22.

[18] B. Zhang, X. Tang, Y. Li, Y. Xu, International Journal of Hydrogen Energy 32 (13) (2007) 23672373.

[19] D. Srinivas, C. V. V. Satyanarayana, H. S. Potdar, P. Ratnasamy, Applied Catalysis A: General 246 (2003) 323-334.

[20] R. J. Gorte, AiChE Journal 56 (2010) 1126-1135.

[21] J. Llorca, N. Homs, P. Ramírez de la Piscina, Journal of Catalysis 227 (2004) 556-560.

[22] J. C. Vargas, S. Libs, A. C. Roger, A. Kiennenman, Catalysis Today 107-108 (2005) 417-425.

[23] F. Romero-Sarria, J. C. Vargas, A. C. Roger, A. Kiennenman, Catalysis Today 133-135 (2008) 149-153.

[24] J. P. Breen, R. Burch, H. M. Coleman, Applied Catalysis B: Environmental 39 (2002) 65-74. 
[25] D. K. Liguras, D. I. Kondarides, X. E. Verykios, Applied Catalysis B: Environmental 43 (2003) 345-354.

[26] E. C. Wanat, K. Venkataraman, L. D. Schmidt, Applied Catalysis A: General 276 (2004) $155-$ 162.

[27] H. Idriss, Platinum Metals Review 48 (2004) 105-115.

[28] M. Araque, L. M. Martínez T, J. C. Vargas, M. A. Centeno, A. C. Roger, Applied Catalysis B: Environmental 125 (2012) 556-566.

[29] L. M. Martínez T, M. A. Araque, J. C. Vargas, A. C. Roger, Applied Catalysis B: Environmental 132-133 (2013) 499-510.

[30] E. Ambroise, C. Courson, A. C. Roger, A. Kiennemann, G. Blanchard, S. Rousseau, X. Carrier, E. Marceau, C. La Fontaine, F. Villain, Catalysis Today 154 (2010) 133-141.

[31] E. Ambroise, C. Courson, A. Kiennenman, A. C. Roger, O. Pajot, E. Samson, G. Blanchard, Topics in Catalysis 52 (2009) 2101-2107.

[32] Y. Madier, C. Descorme, A. M. Le Govic, D. Duprez, Journal of Physical Chemistry B 103 (1999) 10999-11006.

[33] O. H. Laguna, M. A. Centeno, G. Arzamendi, L. M. Gandía, F. Romero-Sarria, J. A. Odriozola, Catalysis Today 157 (2010) 155-169.

[34] L. Cao, L. Pan, C. Ni, Z. Yuan, S. Wang, Fuel Processing Technology 91 (2010) 306-312.

[35] H. Vidal, J. Kaspar, M. Pijolat, G. Colón, S. Bernal, A. Córdon, V. Perrichon, F. Fally, Applied Catalysis B: Environmental 30 (2001) 75-85.

[36] W.Y. Hernandez, F. Romero-Sarria, M.A. Centeno, J.A. Odriozola, The Journal of Physical Chemistry C 114 (2010) 10857-10865.

[37] J. E. Spanier, R. D. Robinson, F. Zhang, S. W. Chan, I. P. Herman, Physical Review B 64 (2001) 2454071-24540713

[38] G. Vlaic, R. Di Monte, P. Fornarsiero, E. Fonda, J. Kaspar, M. Graziani, Journal of Catalysis 182 (1999) 378-389.

[39] C. de Leitenburg, A. Trovarelli, F. Zamar, S. Maschio, G. Dolcetti, Chemical Communication. (1995) 2181-2182.

[40] A. Martínez-Arias, M. Fernández-García, V. Ballesteros, L. N. Salamanca, J. C. Conesa, C. Otero, J. Soria, Langmuir 15 (1999) 4796-4802.

[41] D. Duprez, C. Descorme, T. Birchem, E. Rohart, Topics in Catalysis 16-17 (2001) 49-56.

[42] J. Liu, Z. Zhao, J. Wang, C. Xu, A. Duan, G. Jiang, Q. Yang, Applied Catalysis B: Environmental 84 (2008) 185-195.

[43] T. Yamaguchi, N. Ikeda, H. Hattori, K. Tanabe, Journal of Catalysis 67 (1981) 324-330.

[44] S. Damyanova, J. M. C. Bueno, Applied Catalysis A: General 253 (2003) 135-150.

[45] A. Trovarelli, Catalysis Reviews-science and Engineering 38 (1996) 439-520

[46] T. Tsoncheva, L. Ivanova, C. Minchev, M. Fröba, Journal of Colloid and Interface Science 77 (2003) 407-417.

[47] M. Araque, J. C. Vargas, Y. Zimmermann, A. C. Roger, International Journal of Hydrogen Energy 36 (2011) 1491-1502

[48] C. De Leitenburg, A. Trovarelli, J. Kaspar, Journal of Catalysis 166 (1997) 98-107.

[49] A. Trovarelli, C. De Leitenburg, G. Dolcerri. J. L. Lorca, Jorunal of Catalysis 151 (1995) 111-124

[50] E. B. Pereira, N. Homs, S. Martí, J. L. G. Fierro, P. Ramírez de la Piscina, Journal of Catalysis 257 (2008) 206-214.

[51] M. Slinn, K. Kendall, C. Mallon, J. Andrews, Bioresource Technology 99 (2008) 5851-5858.

[52] Y. Cui, V. Galvita, L. Rihko-Struckmann, H. Lorenz, K. Sundmacher, Applied Catalysis B: Environmental 90 (2009) 29-37.

[53] V. Chiodo, S. Freni, A. Galvagno, N. Mondello, F. Frusteri, Applied Catalysis A: General 381 (2010) 1-7.

[54] D. Wang, D. Montane, E. Chornet, Applied Catalysis A: General 143 (1996) 245-270

[55] D. L. Trimm, Catalysis Today 37 (1997) 233-238.

[56] C. H. Bartholomew, Catalysis Reviews 24 (1982) 67-112.

[57] D. L. Trimm, Catalysis Today 49 (1999) 3-10. 
[58] Y. Cui, V. Galvita, L. Rihko-Struckmann, H. Lorenz, K. Sundmacher, Applied Catalysis B Environmental 90 (2009) 29-37.

[59] L.F. Bobadilla, A. Alvarez, M. I. Dominguez, F. Romero-Sarria, M. A. Centeno, M. Montes, J. A. Odriozola, Applied Catalysis B: Environmental 123-124 (2012) 379-390.

[60] E. A. Sanchez, R. A. Comelli, International Journal of Hydrogen Energy 37 (2012) 14740-14746.

[61] F.Romero-Sarria, J. C. Vargas, A. C. Roger, A. Kiennenman, Catalysis Today 133-135 (2008) 149-153.

[62] A. Corma, G. W. Huber, L. Sauvanaud, P. O`Connor, Journal of Catalysis 247 (2007) 163-171

[63] J. Barrault, J. M. Clacens, Y. Pouilloux, Topics in Catalysis 27 (2004) 137-142.

[64] Y. Madier, C. Descorme, A. M. Le Govic, D. Duprez, The Journal of Physical Chemistry B 103 (1999) 10999-11006.

[65] G. Jacobs, R. A. Keogh, B. H. Davis. Journal of Catalysis 245 (2007) 326-337. 


\section{Figures captions}

Fig. 1. Effect of ruthenium insertion on $C Z$ and CZCo mixed oxide catalysts: (A) XRD diffraction. (B) Raman spectra at room temperature. (*) CZ fluorite cubic structure (o) $\mathrm{Co}_{3} \mathrm{O}_{4} ;(\mathrm{x}) \mathrm{Co}^{0},(\square) \mathrm{SiC}$.

Fig. 2. $\mathrm{H}_{2}$ - TPR profiles for fresh catalysts.

Fig. 3. Evolution of the $\mathrm{H}_{2}$ production in glycerol steam reforming. Conditions: temperature $650^{\circ} \mathrm{C}, \mathrm{H}_{2} \mathrm{O}$ :glycerol molar ratio 9:1 and atmospheric pressure. Thermodynamic value expected using the UNIQUAC model: $6.06 \mathrm{~mol} \mathrm{H}_{2}$ mol Gly.in ${ }^{-1}$.

Fig. 4. Evolution with time of reaction of weighted mean conversions for glycerol steam reforming. $X$ (global conversion), $X_{G}$ (conversion to non-condensable products) and $X_{L}$ (conversion to condensable products). The results are presented for the three intervals of time of liquid fraction recovery $(0-5 \mathrm{~h}, 5-8.5 \mathrm{~h}$ and $8.5-24 \mathrm{~h})$.

Fig. 5. Distribution of non-condensable products in glycerol steam reforming. $\bullet \mathrm{H}_{2}$, $\mathrm{CO}_{2}, \star \mathrm{CO}, \triangle \mathrm{CH}_{4},+\mathrm{C}_{2} \mathrm{H}_{4}$.

Fig. 6. Evolution with time of reaction of principal condensable products in glycerol steam reforming. The results are presented for the three intervals of time of liquid fraction recovery $(0-5 \mathrm{~h}, 5-8.5 \mathrm{~h}$ and $8.5-24 \mathrm{~h})$.

Fig. 7. TPO profiles for spent catalyst after glycerol steam reforming.

Fig. 8. (A) $\mathrm{H}_{2}$ pulse for the first reduction (open symbols) and for second reduction (filled symbols). (B) $\mathrm{O}_{2}$ pulses after a first reduction for fresh catalysts.

Fig. 9. Raman in-situ in reductive and oxidative atmospheres. ( $~ \mathrm{CZ}$ fluorite cubic structure (o) $\mathrm{Co}_{3} \mathrm{O}_{4}$ 


\section{Tables}

Table 1. Composition of mixed oxide catalyst synthesized

\begin{tabular}{ccccccccccc}
\hline \multicolumn{4}{c}{ Experimental (wt. \%) } & \multicolumn{5}{c}{ Theoretical (wt. \%) } \\
\hline Catalysts & $\mathrm{Ce}$ & $\mathrm{Zr}$ & $\mathrm{Co}$ & $\mathrm{Ru}$ & $\mathrm{Ce} / \mathrm{Zr}$ & $\mathrm{Ce}$ & $\mathrm{Zr}$ & $\mathrm{Co}$ & $\mathrm{Ru}$ & $\mathrm{Ce} / \mathrm{Zr}$ \\
\hline $\mathrm{CZ}$ & $\mathrm{NA}$ & $\mathrm{NA}$ & - & - & $\mathrm{NA}$ & 47.7 & 30.9 & - & - & 1.54 \\
\hline $\mathrm{CZCo}$ & 47.0 & 23.1 & 4.9 & - & 2.03 & 47.4 & 23.2 & 5.0 & - & 2.04 \\
\hline $\mathrm{CZRu}$ & 46.2 & 29.4 & - & 0.5 & 1.57 & 47.4 & 30.4 & - & 0.5 & 1.56 \\
\hline $\mathrm{CZCoRu}$ & 48.2 & 23.9 & 4.7 & 0.5 & 2.02 & 49.0 & 23.9 & 4.8 & 0.5 & 2.05 \\
\hline
\end{tabular}

Table 2. Cubic lattice parameter " $a$ ", average crystallite size and textural properties

\begin{tabular}{ccccccc}
\hline Catalysts & $\begin{array}{c}\text { Cubic lattice "a" } \\
(\AA)\end{array}$ & $\begin{array}{c}\text { Average } \\
\text { crystallite size } \\
\text { of CZ }(\mathrm{nm})\end{array}$ & $\begin{array}{c}\text { Average } \\
\text { crystallite } \\
\text { size of } \\
\mathrm{Co}_{3} \mathrm{O}_{4}(\mathrm{~nm})\end{array}$ & $\begin{array}{c}\text { BET surface } \\
\text { area }\left(\mathrm{m}^{2} \mathrm{~g}^{-1}\right)\end{array}$ & $\begin{array}{c}\text { Pore volume } \\
\left(\mathrm{cm}^{3} \mathrm{~g}^{-1}\right)\end{array}$ \\
\hline $\mathrm{CZ}$ & 5.28 & $5.30^{*}$ & 6.3 & - & 11 & - \\
\hline $\mathrm{CZCo}$ & 5.30 & $5.36^{*}$ & 6.0 & 22.6 & 12 & 0.029 \\
\hline $\mathrm{CZRu}$ & 5.29 & $5.30^{*}$ & 5.8 & - & 41 & 0.072 \\
\hline $\mathrm{CZCoRu}$ & 5.29 & $5.32^{*}$ & 5.6 & 18.7 & 16 & 0.035 \\
\hline
\end{tabular}

* Spent catalysts

Table 3. $\mathrm{H}_{2}$-TPR results: hydrogen consumption and $\% \mathrm{Ce}^{4+}$ reduced

\begin{tabular}{ccccc}
\hline \multicolumn{4}{c}{$\mathrm{H}_{2}$ consumption $\left(\mathrm{mmol} \mathrm{H}_{2} \mathrm{~g} \mathrm{catal.}^{-1}\right)$} \\
\hline Catalysts & Total & $\begin{array}{c}\text { Low } \\
\text { temperature } \\
\left(<550^{\circ} \mathrm{C}\right)\end{array}$ & $\begin{array}{c}\text { High } \\
\text { temperature } \\
\left(>550^{\circ} \mathrm{C}\right)\end{array}$ & $\begin{array}{c}\% \mathrm{Ce}^{4+} \\
\text { reduced }\end{array}$ \\
\hline $\mathrm{CZ}$ & 0.76 & $0.00(0 \%)$ & $0.76(100 \%)$ & 45 \\
\hline $\mathrm{CZCo}$ & 1.97 & $0.91(46 \%)$ & $1.06(54 \%)$ & 45 \\
\hline $\mathrm{CZRu}$ & 0.86 & $0.49(57 \%)$ & $0.37(43 \%)$ & 46 \\
\hline $\mathrm{CZCoRu}$ & 2.16 & $1.01(47 \%)$ & $1.15(53 \%)$ & 56 \\
\hline
\end{tabular}

Table 4. Quantification of carbonaceous deposits after glycerol steam reforming obtained by TPD-TPO experiments

\begin{tabular}{ccc}
\hline Spent catalysts & $\begin{array}{c}\text { mmol } \\
\text { C total g catal. }\end{array}$ & $\begin{array}{c}\text { Sc }(\text { mmol C total } \\
\text { mol carbon-converted }\end{array}$ \\
\hline $\mathrm{CZ}$ & 2.82 & 0.24 \\
\hline $\mathrm{CZCo}$ & 2.62 & 0.20 \\
\hline $\mathrm{CZRu}$ & 2.64 & 0.20 \\
\hline $\mathrm{CZCoRu}$ & 1.55 & 0.11 \\
\hline
\end{tabular}

Table 5. $\mathrm{H}_{2}$ consumption and $\mathrm{O}_{2}$ uptake obtained after TPR-TPO 


\begin{tabular}{ccccc}
\hline Catalysts & $\begin{array}{c}\text { First reduction } \\
\mu \mathrm{mol} \mathrm{H} \mathrm{H}_{2} \text { g catal. }^{-1}\end{array}$ & $\begin{array}{c}\text { Oxidation } \\
\mu \mathrm{mol} \mathrm{O} \text {. g catal. }^{-1}\end{array}$ & $\begin{array}{c}\text { Second reduction } \\
\mu \mathrm{mol} \mathrm{H}_{2} \cdot \text { g catal. }^{-1}\end{array}$ & $\mathrm{O}_{2} / \mathrm{H}_{2}$ \\
\hline CZCoRu & 1725 & 660 & 1567 & 0.38 \\
\hline CZCoRh & 1108 & 455 & 1170 & 0.41 \\
\hline
\end{tabular}




\section{Figures}
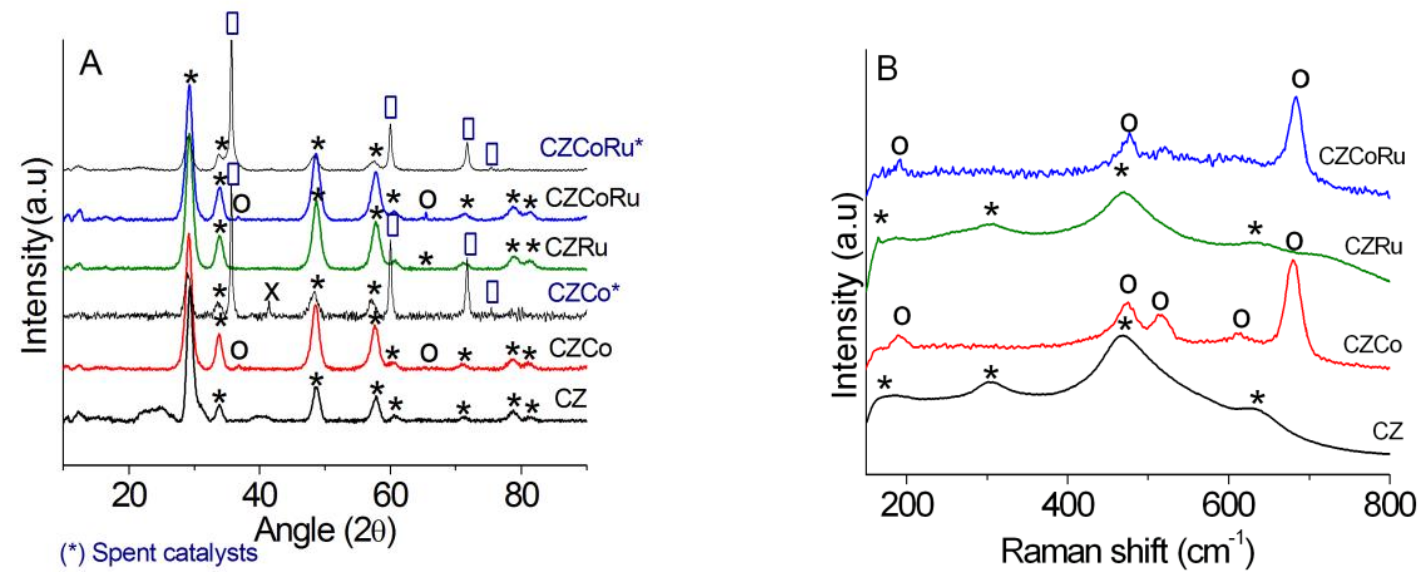

Fig. 1. Effect of ruthenium insertion on $C Z$ and CZCo mixed oxide catalysts: (A) XRD diffraction. (B) Raman spectra at room temperature. (*) $\mathrm{CZ}$ fluorite cubic structure (o) $\mathrm{Co}_{3} \mathrm{O}_{4} ;(\mathrm{x}) \mathrm{Co}^{0},(\square) \mathrm{SiC}$

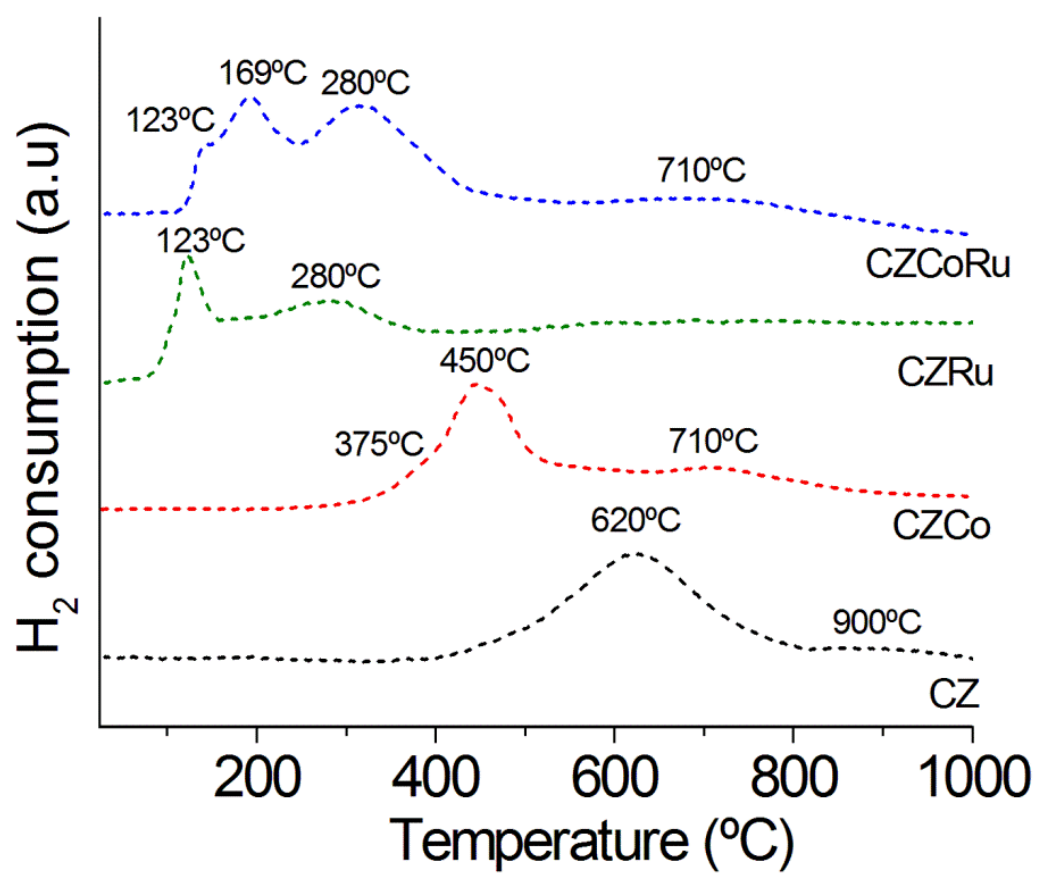

Fig. 2. $\mathrm{H}_{2}$ - TPR profiles for fresh catalysts 


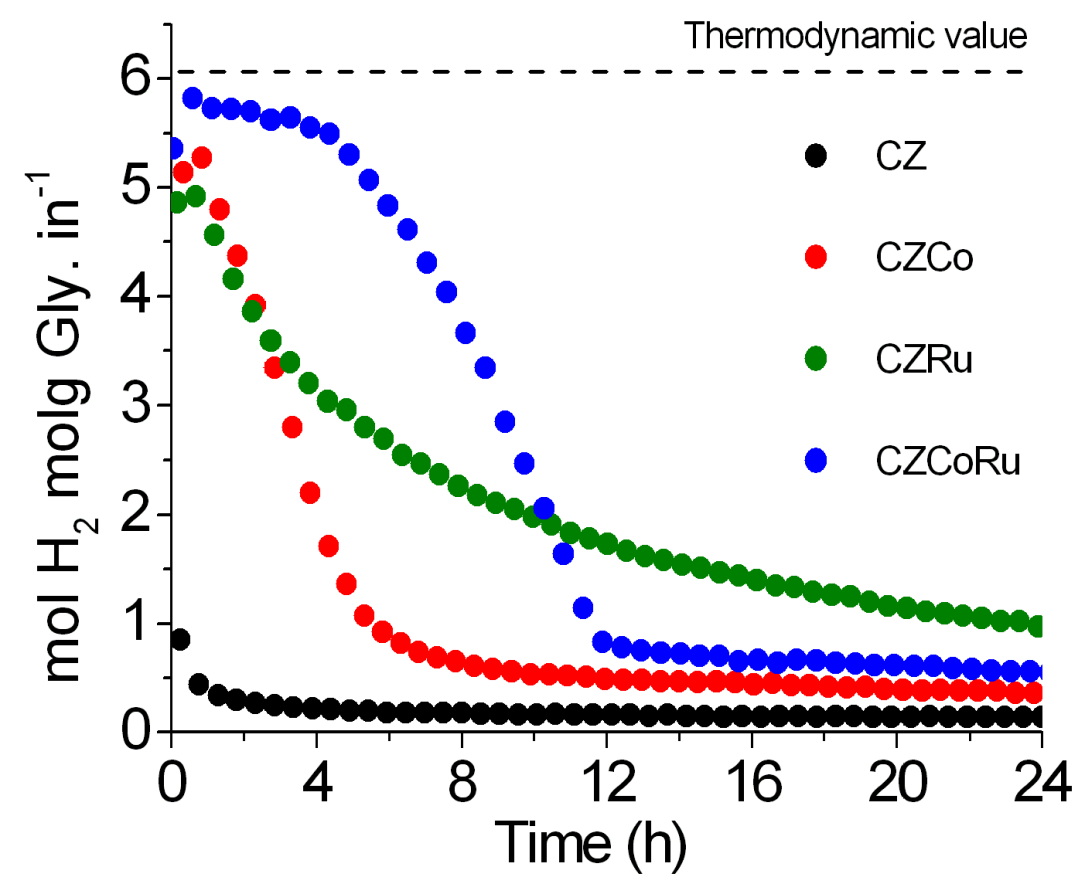

Fig. 3. Evolution of the $\mathrm{H}_{2}$ production in glycerol steam reforming. Conditions: temperature $650^{\circ} \mathrm{C}, \mathrm{H}_{2} \mathrm{O}$ :glycerol molar ratio 9:1 and atmospheric pressure. Thermodynamic value expected using the UNIQUAC model: $6.06 \mathrm{~mol} \mathrm{H}_{2}$ mol Gly.in ${ }^{-1}$
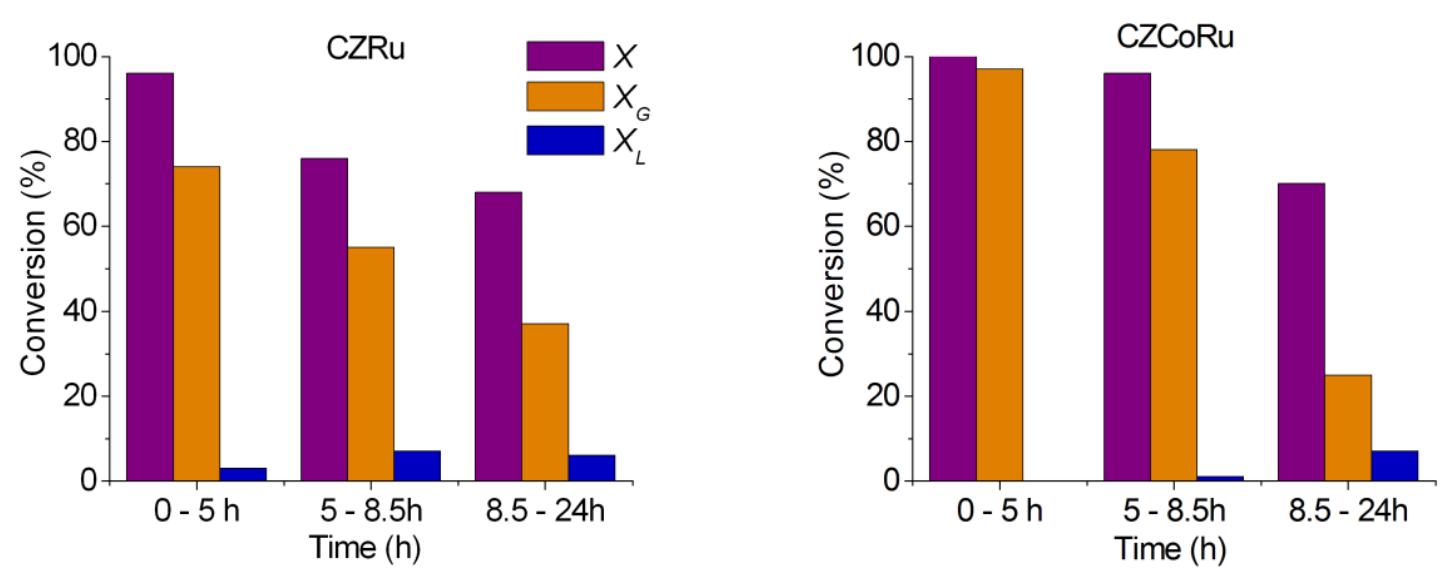

Fig. 4. Evolution with time of reaction of weighted mean conversions for glycerol steam reforming. $X$ (global conversion), $X_{G}$ (conversion to non-condensable products) and $X_{L}$ (conversion to condensable products). The results are presented for the three intervals of time of liquid fraction recovery $(0-5 \mathrm{~h}, 5-8.5 \mathrm{~h}$ and $8.5-24 \mathrm{~h})$ 

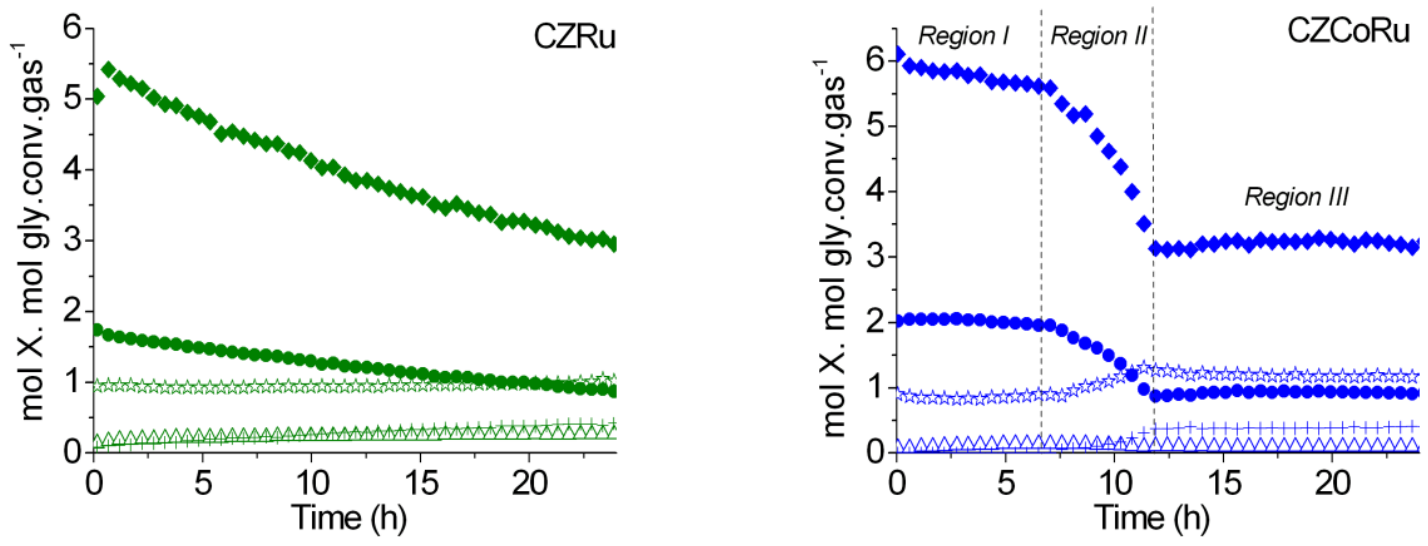

Fig. 5. Distribution of non-condensable products in glycerol steam reforming. $\bullet \mathrm{H}_{2}, \bullet \mathrm{CO}_{2}$, $\star \mathrm{CO}, \triangle \mathrm{CH}_{4},+\mathrm{C}_{2} \mathrm{H}_{4}$
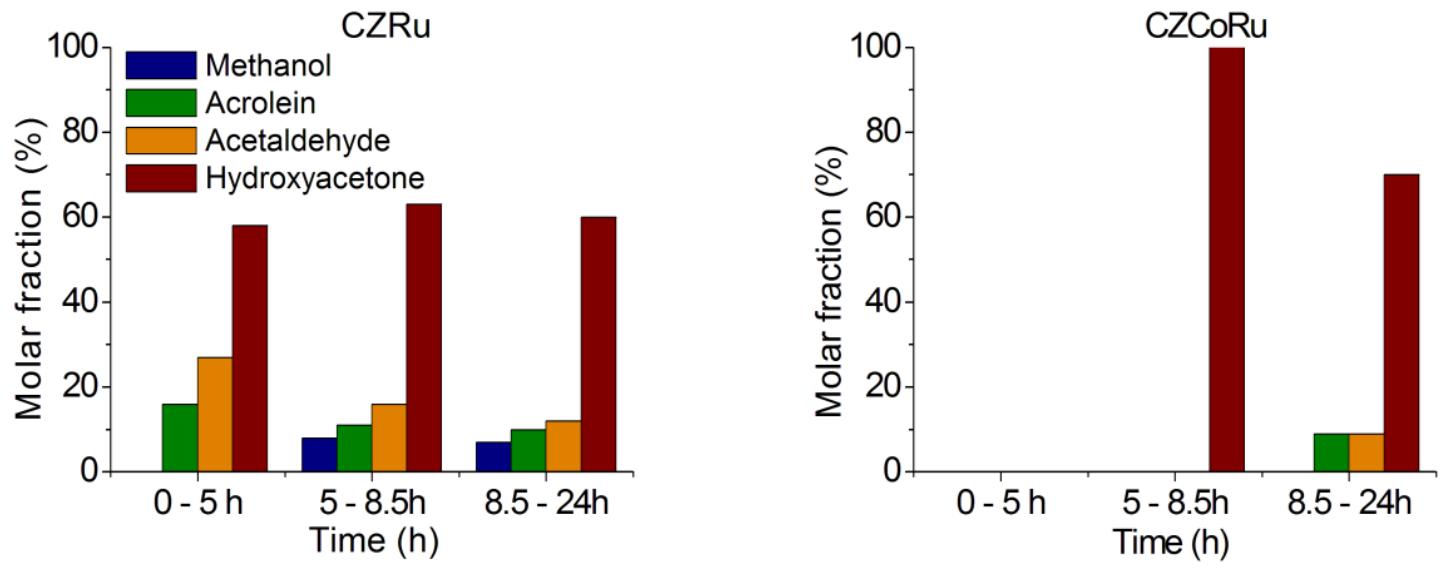

Fig. 6. Evolution with time of reaction of principal condensable products in glycerol steam reforming. The results are presented for the three intervals of time of liquid fraction recovery $(0-5 \mathrm{~h}, 5-8.5 \mathrm{~h}$ and $8.5-24 \mathrm{~h})$. 


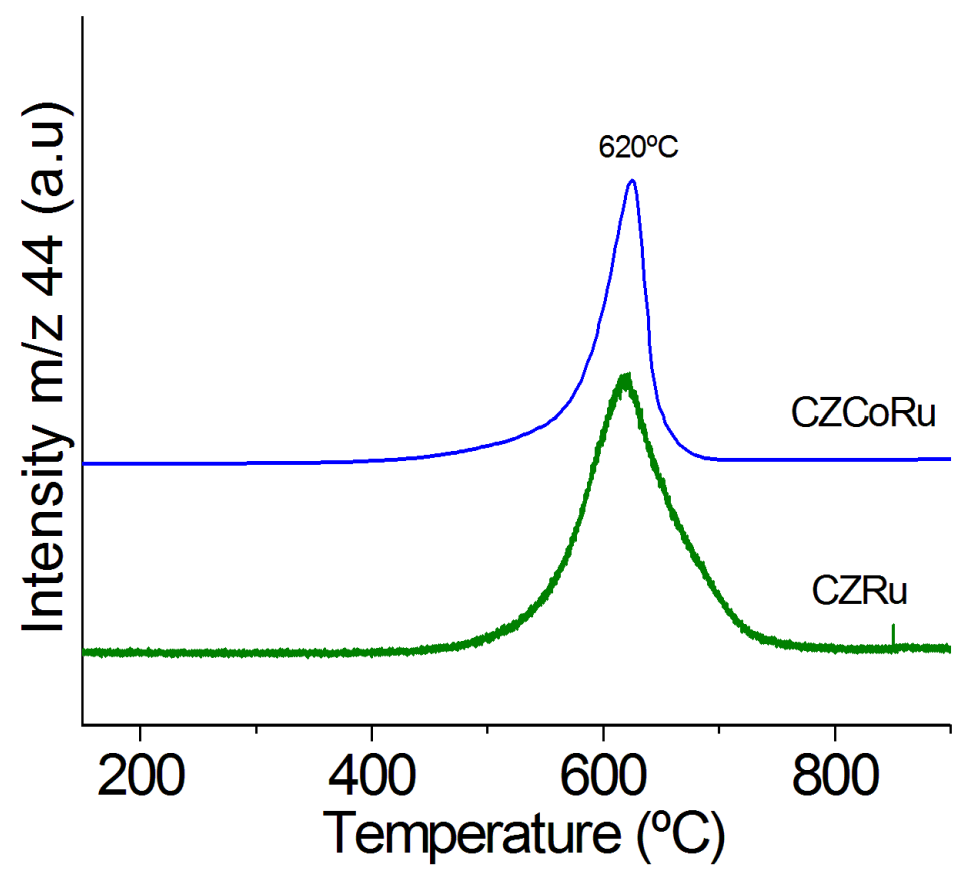

Fig. 7. TPO profiles for spent catalyst after glycerol steam reforming.
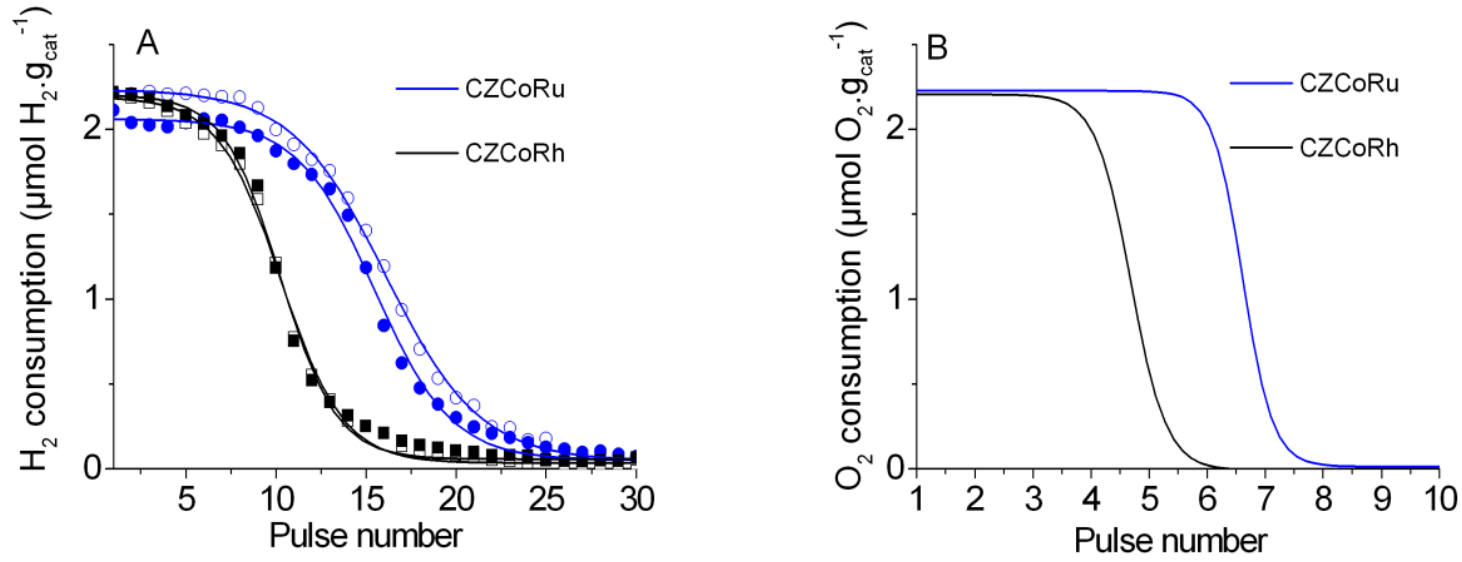

Fig. 8. (A) $\mathrm{H}_{2}$ pulse for the first reduction (open symbols) and for second reduction (filled symbols). (B) $\mathrm{O}_{2}$ pulses after a first reduction for fresh catalysts. 

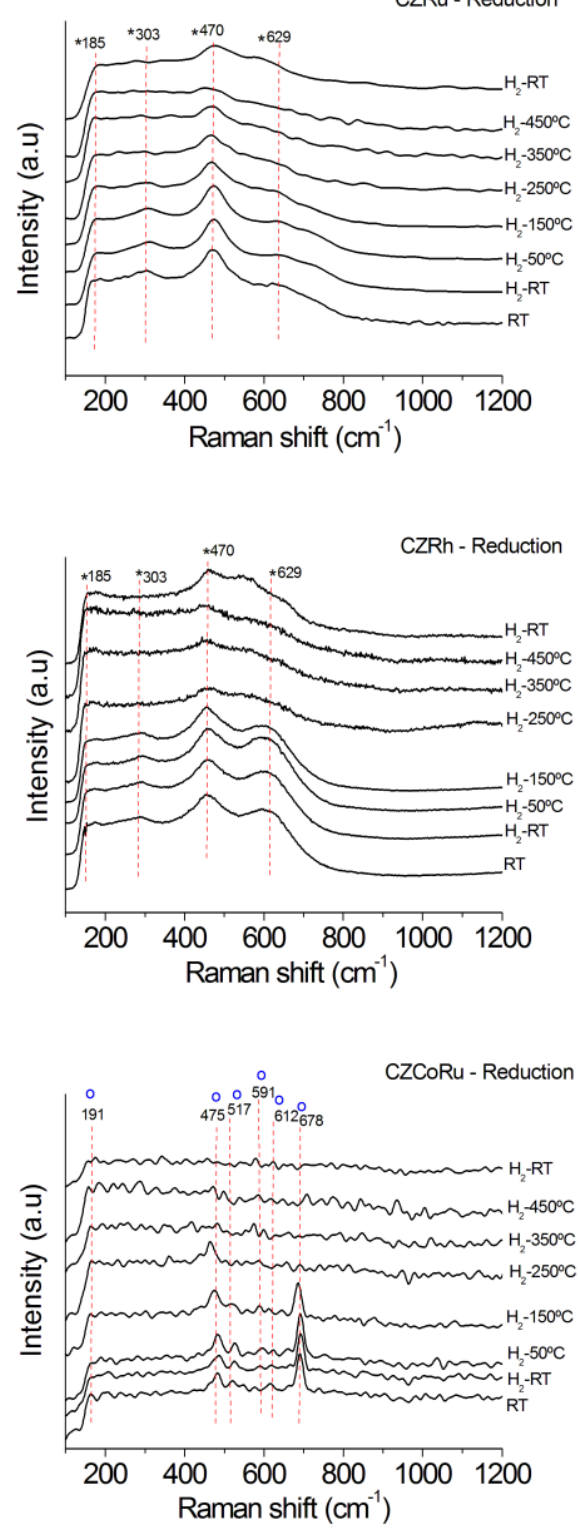

CZCoRh - Reduction

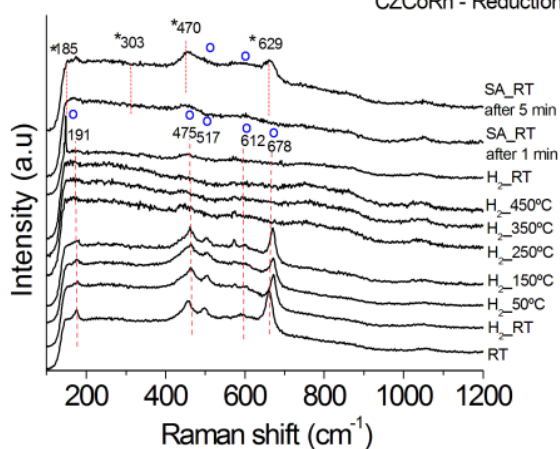

CZRu - Oxidation

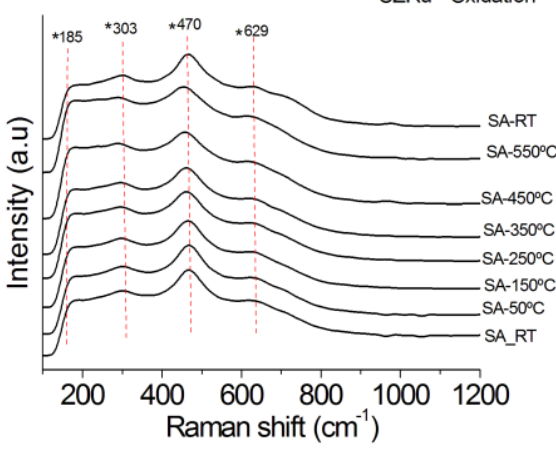

CZRh - Oxidation

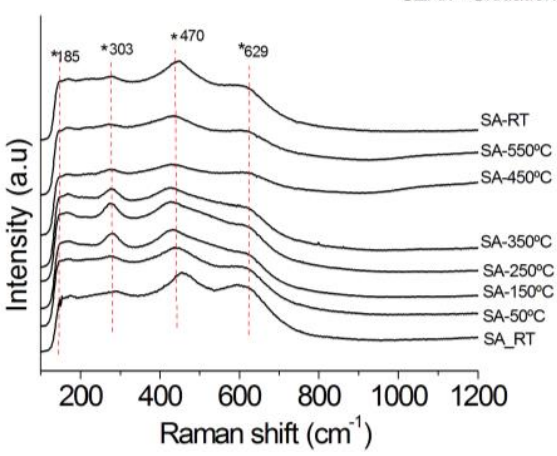

CZCoRu - Oxidation

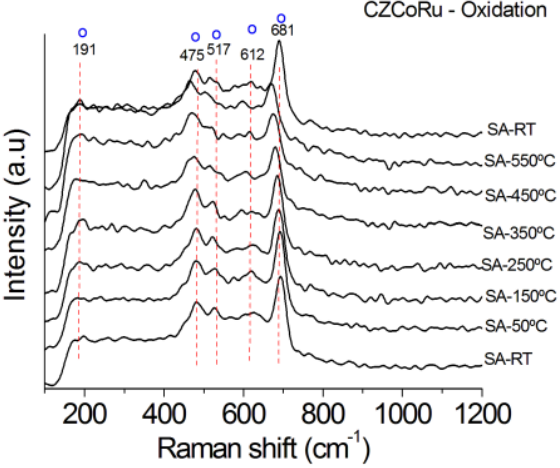

CZCoRh - Oxidation

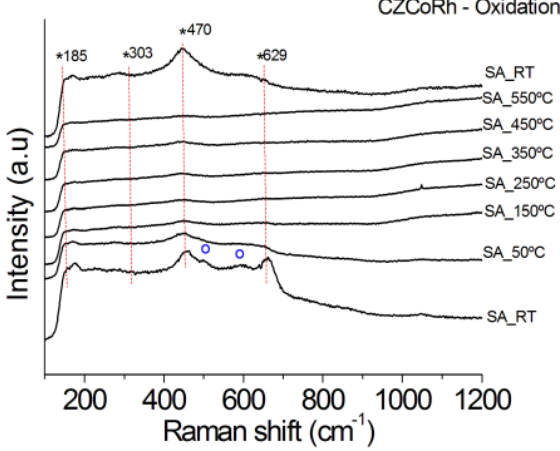

Fig. 9. Raman in-situ in reductive and oxidative atmospheres. ( $($ ) CZ fluorite cubic structure (o) $\mathrm{Co}_{3} \mathrm{O}_{4}$ 